\title{
Penetrometer testing in a calcareous silt to explore changes in soil strength
}

\author{
S.H. Chow ${ }^{1}$, C.D. O’Loughlin², Z. Zhou ${ }^{3}$, D.J. White ${ }^{4}$ \& M.F. Randolph ${ }^{5}$
}

Words: 6580 (main text), Figures: 16, Tables: 5

${ }^{1}$ Corresponding Author

Research Fellow, Centre for Offshore Foundation Systems

The University of Western Australia

35 Stirling Highway, Crawley WA 6009, Perth, Australia

Phone: +61 864886930

Fax: +61 864881044

E-mail: shiaohuey.chow@uwa.edu.au

${ }^{2}$ Associate Professor, Centre for Offshore Foundation Systems

The University of Western Australia

35 Stirling Highway, Crawley WA 6009, Perth, Australia

Phone: +61 864886488

Fax: +61 864881044

E-mail: conleth.oloughlin@uwa.edu.au

${ }^{3} \mathrm{PhD}$ candidate, Centre for Offshore Foundation Systems

The University of Western Australia

35 Stirling Highway, Crawley WA 6009, Perth, Australia

E-mail: zefeng.zhou@research.uwa.edu.au

${ }^{4}$ Professor of Infrastructure Geotechnics, Engineering and the Environment

University of Southampton

Highfield Southampton SO17 1BJ35, UK

Phone: +023 80596859

E-mail: david.white@soton.ac.uk

${ }^{5}$ Professor, Centre for Offshore Foundation Systems

The University of Western Australia

35 Stirling Highway, Crawley WA 6009, Perth, Australia

Phone: +61 864883075

Fax: +61 864881044

E-mail: mark.randolph@uwa.edu.au 


\title{
PENETROMETER TESTING IN A CALCAREOUS SILT TO EXPLORE CHANGES IN SOIL STRENGTH
}

\author{
S.H. Chow, C.D. O’Loughlin, Z. Zhou, D.J. White \& M.F. Randolph
}

\begin{abstract}
This paper describes a centrifuge study using a range of penetrometer tests (T-bar, piezocone and free-fall piezocone) to explore changes in strength of reconstituted normally-consolidated natural calcareous silt. Various penetrometer test procedures were applied to measure the penetration resistance in this sample. The penetrometer test procedures included monotonic, cyclic and twitch-type movements as well as pauses for pore pressure dissipation. These mobilised combinations of partial or full remoulding, strain softening, consolidation and viscous rate effects. The penetrometer resistance - representing a proxy for strength - reduced by a factor of 4.1 from drained to undrained conditions (at the lowest fully undrained penetration rate). In undrained conditions, viscous enhancement of the penetration resistance raised the tip and shaft resistance in free fall piezocone tests by $\sim 2.8$ and $\sim 3.6$ times respectively. The 'restart' resistance immediately after the dissipation tests was $\sim 2.5$ times higher than the resistance prior to dissipation, giving an indication of consolidation-induced strength gain. The 'twitch' test (using sequential steps decreasing the velocity) captured drainage and viscous rate effects, and also gave a 'restart' resistance that showed even greater consolidation effects than from a dissipation test. Overall, the different penetrometer test types and procedures measured resistances in the same soil sample that varied by a factor exceeding 20 from highest to lowest, resulting from different penetration rates and history, due to strain rate, strain level (or remoulding), and consolidation. An expression for the monotonic penetration resistance combining drainage and viscous rate effects was fitted to the response of all tests, spanning $>7$ orders of magnitude in strain rate.
\end{abstract}

\section{Keywords:}

Penetrometers, strain rate, drainage, offshore 


\section{INTRODUCTION}

There is a requirement in offshore geotechnical design to predict the appropriate soil strength reliably during different stages in the life of an offshore foundation, for example installation, preloading, service and decommissioning. During the different stages, a soft soil supporting an offshore foundation may be subjected to shear strength changes arising from partial or full remoulding, strain softening, consolidation and viscous rate effects. Different design applications and different types of soil characterisation tests mobilise different strain rates and different levels of remoulding and reconsolidation, as illustrated in Fig. 1.

In situ penetrometer tests (cone or full-flow penetrometers) have the advantage of being able to model the above mentioned effects through procedures such as cyclic penetration and extraction, varying the penetrate rate, and allowing pore pressure dissipation (Randolph et al. 2007; DeJong et al. 2010). These allow the variation in strength due to strain rate, remoulding and consolidation to be explored. The measured penetration resistance can also be used directly for geotechnical analysis, without the intermediate step of conversion to soil strength (e.g. Lee \& Randolph 2011).

In situ penetrometer tests have been studied extensively, resulting in several recommended practices and standards for penetration testing (e.g. DeJong et al. 2010; Lunne et al. 2011; ASTM 2012; ISO 2014). Many of the recommendations are made based on investigation in clayey sediments or well-characterised 'standard soil' such as kaolin clay. More novel penetrometers and penetrometer test protocols have been developed, with much of their performance and potential (e.g. revealing the variation in soil resistance shown in Fig. 1) demonstrated using kaolin and other non-calcareous clays (Chung et al. 2006; Lehane et al. 2009; DeJong et al. 2010; Mahmoodzadeh et al. 2015; Colreavy et al. 2016a). Relative to this focus, there have been rather few equivalent studies in the calcareous material commonly found in offshore regions of Australia. Calcareous sediments are known to be problematic with high carbonate content, in-situ void ratio and sensitivity, leading to greater uncertainty associated with the available soil resistance compared to non-calcareous soils (e.g. Jewell \& Korshid 1988; Mao \& Fahey 2003; Erbrich \& Hefer 2002; Koh et al. 2017). It is therefore important to assess how the different effects (remoulding, strain softening, drainage/consolidation, strain rate effects) are reflected in the penetration resistance measured in penetrometer tests in calcareous soils.

This study examines the above effects using centrifuge piezocone and full-flow penetrometer tests in a reconstituted calcareous silt sediment. The penetrometer test program covers 
monotonic penetration (with variable rate), free-fall penetration (changing rate), cyclic and pore pressure dissipation tests. Free-fall piezocone tests (operative strain rate, $v / d$ of 100 to $1600 \mathrm{~s}^{-}$ ${ }^{1}$ ) not only provide penetration resistance and pore pressure dissipation data, but also allow for the examination of viscous rate effects, extending the viscous strain rate range covered by monotonic (static) penetrometer tests (operative strain rate, $v / d$ of 0.3 to $10 \mathrm{~s}^{-1}$ ).

The paper first discusses the laboratory investigation of index properties of the calcareous silt, followed by the results and interpretation of static, cyclic and free-fall penetrometer tests.

\section{INDEX PROPERTIES OF CALCAREOUS SILT}

The penetrometer tests were conducted in a sample of calcareous silt reconstituted from bulk samples of an offshore sediment recovered at shallow depth by box cores. The index properties of the reconstituted calcareous silt are listed in Table 1. The properties were obtained through laboratory classification and element tests conducted at the University of Western Australia, UWA, in accordance with relevant Australian Standards and ASTM Standards. The calcareous silt has a plasticity index of 28 and specific gravity of 2.71. It is high in carbonate content (73\%) with $1 \%$ organic content and has a natural water content of approximately $120 \%$. The particle size distribution (PSD) curves of the sample are presented in Fig. 2 with mean size, $d_{50}$ of approximately $0.001 \mathrm{~mm}$. With the carbonate content of $73 \%$ and $d_{50} \sim 0.001 \mathrm{~mm}$, the soil can be classified as carbonate mud in accordance with the offshore sediment classification approach proposed by Walker \& Clark (1977). However, the Walker \& Clark (1977) approach does not provide indication of the engineering behaviour (Dutt \& Ingram 1990). Following the USCS, the soil can also be classified as inorganic silt, MH. Hence the soil may be more appropriately classified as 'carbonate muddy SILT' than carbonate mud.

Also included in Table 1 and Fig. 2 for comparison are the properties and PSD curves of other calcareous sediments: Gorgon muddy silt and Gorgon seabed silt from the North West Shelf (Mao \& Fahey 2003) and Laminaria silty clay from the Timor Sea (Erbrich \& Hefer 2002). Table 1 also includes the properties of (UWA) kaolin clay, as many of the laboratory penetrometer investigations have used kaolin clay. As observed from Fig. 2, the calcareous silt PSD is very similar to Gorgon muddy silt. The critical state parameters of the calcareous silt were established from a combination of simple shear tests $(M=1.62)$ and Rowe cell tests $(\lambda=$ 0.287, $\kappa=0.036$ ). Table 1 shows that the critical state parameters of the calcareous silt are in a similar range to other calcareous sediments. 


\section{CENTRIFUGE TEST DESCRIPTION}

\section{Penetrometers}

A T-bar penetrometer and a piezocone penetrometer were used in this study and are shown in Fig. 3. The dimension and instrumentation of these penetrometers are detailed in Table 2. The piezocone (Fig. 3a) had an overall length of $120 \mathrm{~mm}$ and a mass of $29 \mathrm{~g}$ and was either deployed in free-fall mode, or jacked using an adaptor to extend the shaft such that it could be attached to the same actuator used to penetrate the T-bar penetrometer. The T-bar penetrometer had a diameter $d=5 \mathrm{~mm}$ and length, $L=20 \mathrm{~mm}$ giving a geometrical aspect ratio of $L / d=4$, which is sufficient to simulate an idealised infinitely long bar (Chung \& Randolph 2004). The load cell shaft immediately behind the T-bar had a diameter of $4.5 \mathrm{~mm}$ such that the ratio of shaft to probe area is 0.16. Both penetrometers were calibrated for load and temperature. The temperature sensitivity of the T-bar and piezocone penetrometer is $6.6 \mathrm{kPa} /{ }^{\circ} \mathrm{C}$ and $7.3 \mathrm{kPa} /{ }^{\circ} \mathrm{C}$ respectively, which for a $1{ }^{\circ} \mathrm{C}$ variation in temperature over the depth of the sample corresponds to an average penetration resistance shift of $0.35 \mathrm{kPa} / \mathrm{m}$. As shown later, this is negligible relative to the gradient of penetration resistance (due to soil strength) with depth.

\section{Sample preparation}

The penetrometer tests were conducted in a single soil sample that was reconstituted by mixing the calcareous silt at a targeted water content of $145 \%$. The slurry was mixed continuously for about 48 hours and then poured slowly into a centrifuge strongbox measuring (internally) $650 \mathrm{~mm}$ long, $390 \mathrm{~mm}$ wide and $325 \mathrm{~mm}$ deep. A $10 \mathrm{~mm}$ layer of sand was placed at the base of the strongbox (i.e. before pouring the slurry) overlayed by a geosynthetic drainage layer. The sample was consolidated under self-weight in the centrifuge at an acceleration of $100 \mathrm{~g}$ for 5 days, during which time additional slurry was added to ensure that the final sample height was approximately $230 \mathrm{~mm}$. A $55 \mathrm{~mm}$ water layer was maintained at the sample surface to ensure saturation. The reconstituted sample has an effective unit weight profile of $\gamma^{\prime}=4.82+0.04 \mathrm{z}$ $\mathrm{kN} / \mathrm{m}^{3}$, where $z$ is the prototype sample depth and where $\gamma^{\prime}$ was inferred from water content measurements taken at the end of testing.

\section{Centrifuge test details and procedures}

The centrifuge tests were carried out at an acceleration of $100 \mathrm{~g}$ using the fixed beam Acutronic 661 centrifuge at the Centre for Offshore Foundation Systems in The University of Western Australia. The centrifuge has a $1.8 \mathrm{~m}$ radius with a maximum payload of $200 \mathrm{~kg}$ at an 
acceleration of $200 \mathrm{~g}$. The centrifuge test program is summarised in Table 3. The static penetrometer test program was designed to determine: (a) penetration resistance of the 'intact' soil through monotonic T-bar and piezocone penetration tests; (b) remoulded penetration resistance and strain softening parameters through cyclic T-bar degradation tests; (c) consolidation parameters through piezocone dissipation tests; and (d) drainage and viscous rate parameters through T-bar and piezocone variable rate penetration tests, including so-called 'twitch' tests where the penetration rate was decreased progressively in steps (House et al. 2001). Free-fall piezocone (FFP) tests complemented and extended the static penetrometer test program, particularly the investigation of viscous rate effects in the high strain rate region. This also addressed the question of whether FFP results can be interpreted in terms of conventional static penetrometer test results, and therefore provide equivalent inputs for design.

For ease of reference, tests are identified as XmmmYn, where $\mathrm{X}$ is either $\mathrm{D}$ for a free-fall (dynamic) piezocone test, $\mathrm{S}$ for a jacked (static) piezocone test, or $\mathrm{T}$ for a T-bar test; mmm refers to either the penetration velocity in a static test or the impact velocity in a free-fall test (both in $\mathrm{m} / \mathrm{s}$ ) and $\mathrm{Y}$ refers to the test type, where $\mathrm{C}$ represents a cyclic test, $\mathrm{D}$ a dissipation test, $\mathrm{M}$ a monotonic penetration test, $\mathrm{T}$ a twitch test; and $\mathrm{n}$ is a numeric character representing the test recurrence ( 1 for the first test, 2 for the second etc.) For instance, Test S0.003D refers to a static piezocone test at $v=0.003 \mathrm{~m} / \mathrm{s}$ involving dissipation test(s).

The centrifuge testing arrangement for both the static penetrometer and free-fall penetrometer tests is shown in Fig. 4. The penetrometers were jacked in using an electrical actuator covering penetration velocities, $v$ that spanned across 5 orders of magnitude between $1 \times 10^{-6}$ and $0.1 \mathrm{~m} / \mathrm{s}$ giving non-dimensional velocities, $V^{\prime}=v d_{e} / c_{h}$ that ranged between 0.01 and 2979 , where $d_{e}$ is the diameter of a circle with the same projected area as the penetrometer (Chung et al. 2006) and $c_{h}$ is the coefficient of consolidation deduced from dissipation testing (often loosely referred to as 'horizontal' coefficient of consolidation, although the difference relative to $c_{v}$ determined from laboratory oedeometer tests is more complex). The cyclic and twitch test procedures are described in subsequent sections.

To minimise boundary effects, a spacing of 7.5 penetrometer diameters was provided between a penetrometer test and rigid boundary or adjacent tests. This spacing is considered adequate as the estimated plastic zone of the piezocone is approximately 5.3 diameters using cavity expansion theory ( $R_{e p}=R I_{r}^{0.5}$ where $R_{e p}$ is the radius of the elastic-plastic boundary, $R$ the 
piezocone radius and $I_{r}$ the average rigidity index of the calcareous silt at the sample mid height estimated as $I_{r}=113$ using the Modified Cam Clay constitutive model).

The test setup and procedure for the free-fall piezocone tests are described in Chow et al. (2014, 2017). The piezocone was installed dynamically using a guide to prevent lateral movement during free-fall. For selected tests, the piezocone was left in the soil after installation and until at least $90 \%$ dissipation of the excess pore pressure. The centrifuge was then spun down and the piezocone embedment depth measured directly using a steel rule (to provide a comparison with that derived from the accelerometer measurements).

Pore pressure dissipation tests were also conducted during selected static and free-fall piezocone tests to provide profiles with depth of the coefficient of consolidation. To ensure the reliability of the dissipation test results, saturation checks of the pore pressure transducer filter were performed before and after several of the tests by cycling the penetrometer up and down in the free water above the soil. Satisfactory saturation was indicated by a rapid response with little or no hysteresis in the data.

\section{PENETROMETER TEST RESULTS AND ANALYSIS}

\section{Intact and remoulded penetration resistance}

The primary measure of intact and remoulded penetration resistance was obtained through monotonic and cyclic T-bar tests conducted at a penetration velocity, $v=3 \mathrm{~mm} / \mathrm{s}$. Without prior information about the soil parameters, the penetration velocity was chosen on the expectation that undrained conditions would be mobilised. The (nominally) 'horizontal' coefficient of consolidation, $c_{h}$ for the calcareous silt was assessed from penetrometer dissipation data (described later), to give a non-dimensional velocity, $V^{\prime}=v d_{e} / c_{h}=68$, where $d_{e}=11.3 \mathrm{~mm}$ for the T-bar and $c_{h}=15.7 \mathrm{~m}^{2} / \mathrm{yr}\left(0.5 \mathrm{~mm}^{2} / \mathrm{s}\right)$ at a mid-sample height of $10 \mathrm{~m}$. The effect of drainage on the penetration resistance is discussed further in the section on consolidation and viscous rate effects.

Fig. 5 shows the T-bar net penetration resistances profiles for the sample near the beginning and end of the seven day testing program. All T-bar penetrometer tests involved monotonic penetration and extraction, in addition to an episode of cyclic remoulding at a predetermined depth during penetration. This involved cycling the penetrometer vertically for 20 cycles (a cycle defined as both penetration and extraction) with a cyclic amplitude of either $20 \mathrm{~mm}$ or $30 \mathrm{~mm}$ (4 or 6 times the T-bar diameter). In addition to the remoulded resistance, the cyclic 
remoulding phase of the test also provided a means of checking for offsets in the zero resistance measurement at depth and estimation of strain softening parameters (Randolph et al. 2007). In Fig. 5, the T-bar net penetration resistance, $q_{T-b a r}$ was corrected for any zero resistance offsets detected by the T-bar load cell and the unequal area above and below the T-bar probe (Randolph et al. 2007). The measured T-bar net penetration resistance, $q_{T-b a r}$, is seen to increase by 7 to $14 \%$ over the course of the seven day testing period.

The cyclic remoulding tests indicate that the calcareous silt has a higher sensitivity, $S_{t}$, (in terms of penetration resistance) than kaolin clay; $S_{t}$ is in the range 3.8 to 4.6, compared with $S_{t}=2$ to 2.5 for kaolin clay (e.g. Colreavy et al. 2016b; Yuan et al. 2017) as summarised in Table 4. High sensitivity is often reported for calcareous seabeds, such as those encountered at Yolla and Trefoil (Bass Strait, offshore Australia), where in-situ cyclic remoulding tests indicate that the (penetration) sensitivity is typically as high as $S_{t}=20$ (Erbrich 2005). A lower sensitivity is expected in reconstituted soils due to the breakdown in structure that takes place during mixing as a slurry.

The T-bar cyclic remoulding tests also allow the cyclic degradation curves to be established, as shown in Fig. 6. The cycle numbering scheme uses 0.25 for the first penetration stage, 0.75 for the first extraction stage and so forth, following Randolph et al. (2007). To establish the strainsoftening parameters, the cyclic degradation curves are fitted by Einav \& Randolph (2005):

$$
\frac{q}{q_{\text {int }}}=\delta_{\text {rem }}+\left(1-\delta_{\text {rem }}\right) e^{-3 \xi / \xi_{95}}
$$

where $q$ is the penetration resistance at cycle $i, q_{\text {int }}$ the intact penetration resistance, $\delta_{\text {rem }}$ the ratio of fully remoulded and initial penetration resistance, $\xi$ the average magnitude of accumulated plastic shear strain undergone by soil elements passing through the flow mechanism after each penetration or extraction stage and $\xi_{95}$ the value of $\xi$ required for $95 \%$ remoulding (i.e. 95\% of the reduction from intact to fully remoulded resistance). The strain softening parameters established through least-square fitting are summarised in Table 4, with $\xi_{95}$ in the range 6.5 to 6.9 .

Monotonic piezocone tests were also conducted at a penetration velocity, $v=0.003 \mathrm{~m} / \mathrm{s}\left(V^{\prime}=\right.$ $v d / c_{h}=60$ ). The piezocone net resistance, $q_{\text {net }}$ (computed using the calibrated unequal area ratio, $\alpha_{\text {cone }}=0.85$ according to Lunne et al. 2011) is plotted alongside the $q_{T-b a r}$ profiles in Fig. 5 . The T-bar net penetration resistance, $q_{T-b a r}$, is approximately $25 \%$ higher than the piezocone net penetration resistance, $q_{\text {net }}$ (Fig. 5), which is contrary to observations made by Low et al. 
(2010) for clays, where on average, $q_{\text {net }}$ was $12.5 \%$ higher than $q_{T-b a r}$ and also in calcareous sediments in Bass Strait where the average T-bar resistance was typically 30 to $40 \%$ lower than the piezocone resistance (Erbrich 2005). As noted later, the higher $q_{T-b a r}$ is considered to be at least partly because the minimum undrained net penetration resistance was observed at $V^{\prime}=7$ for the T-bar and $V^{\prime}=60$ for the piezocone, such that the T-bar profiles in Fig. 5 are affected by strain rate effects.

\section{Consolidation properties}

The coefficient of consolidation, $c_{h}$ of the calcareous silt was determined from static and freefall piezocone (Tests S0.003D, S0.1D and Test D5D) pore pressure dissipation tests conducted at various penetration depths using the Teh \& Houlsby (1991) solution.

Dissipation curves from these tests are presented in Fig. 7. The dissipation curves of the higher penetration velocity static piezocone test (S0.1D with $v=0.1 \mathrm{~m} / \mathrm{s}$ ) and the free-fall piezocone test (D5D with impact velocity, $v_{i}=4.7 \mathrm{~m} / \mathrm{s}$ ) commence with a negative excess pore pressure, which becomes positive over a period of up to $10 \mathrm{~s}$ after the piezocone halted in the soil. The dissipations curves then become tolerably coincident, similar to comparisons of static and freefall piezocone dissipation tests in kaolin (Chow et al. 2014). The initial rise in the pore pressure response - observed in all tests may reflect redistribution of pore pressures from the face to the shoulder of the cone (Chai et al. 2012; Mahmoodzadeh et al. 2015; Colreavy et al. 2016b). For the FFP, a further contribution to the initially low excess pore pressure may be the effect of the soil being rapidly pushed radially outwards as the tip passes, creating suction against the cone wall (Chow et al. 2014). These effects are accounted for by estimating the initial pore pressure, $u_{i}$ at time $t=0$ using the Sully et al. (1999) root time extrapolation method.

Fig. 7b shows the same data using non-dimensional consolidation time defined as (Teh and Houlsby, 1991):

$$
T^{*}=\frac{C_{h} t}{R^{2} \sqrt{I_{r}}}
$$

where $R$ is the penetrometer radius and the rigidity index, $I_{r}=G / s_{u}$. The undrained shear strength, $s_{u}$, was estimated from the T-bar penetration tests using the commonly adopted capacity factor, $N_{T \text {-bar }}=10.5$, and $G$ is the elastic shear modulus, estimated here using the Modified Cam Clay constitutive model: 


$$
G=\frac{3(1-2 v)}{2(1+v)} \frac{p^{\prime}(1+e)}{\kappa}
$$

where $v$ is the Poisson's ratio, $\kappa$ the slope of swelling line, $p^{\prime}$ the mean effective stress and $e$ the void ratio. Eq. 3 gives $I_{r}=108$ to 113, which when used in Eq. 2, provides the best agreement between the measured and theoretical dissipation curves when the coefficient of consolidation is in the range $c_{h}=6.1$ to $24.7 \mathrm{~m}^{2} /$ year. The $c_{h}$ data are shown at their corresponding dissipation depths in Fig. 8 together with coefficients of vertical consolidation, $c_{v}$ measured from Rowe cell tests, and $c_{h}$ determined from $1 \mathrm{~g}$ piezoball dissipation tests using the Mahmoodzadeh et al. (2015) solution. The latter piezoball $c_{h}$ data were obtained from piezoball dissipation tests conducted in $150 \mathrm{~mm}$ diameter tubes of the same reconstituted calcareous silt, but with a maintained vertical stress of approximately $12 \mathrm{kPa}$ to ensure that the soil remained in a normally consolidated state. The experimental $c_{h} / c_{v}$ ratio for the calcareous silt ranges between 1.75 and 2.5, lower than the corresponding theoretical value, which may be expressed as $3(1-v) /(1+v)(\lambda / \kappa)^{0 \cdot 75}=7.66$ (for $\left.v=0.3\right)$ (Mahmoodzadeh et al. 2015).

\section{Consolidation and viscous strain rate effects}

The penetration resistance of a cone or full-flow penetrometer is well known to depend on the drainage generated during penetration and viscous rate effects (e.g. Finnie \& Randolph 1994; House et al. 2001; Randolph \& Hope 2004; Chung et al. 2006; Lehane et al. 2009; Lee \& Randolph 2011; DeJong \& Randolph 2012; Mahmoodzadeh \& Randolph 2014; Colreavy et al. 2016a).

To quantify the influence of drainage in penetrometer tests, the penetration rate is defined using a non-dimensional velocity term, $V=v d / c_{v}$ or $V^{\prime}=v d_{e} / c_{h}$ where $v$ is the penetration velocity, $d_{e}$ is the diameter of a circle with the same projected area as the penetrometer (Chung et al. 2006), and $c_{v}$ and $c_{h}$ are the coefficients of vertical (i.e. from laboratory oedometer tests) and 'horizontal' (i.e. from dissipation tests) consolidation respectively.

The transition between fully drained and undrained conditions occurs over $\sim 4$ orders of magnitude variation in $V$. Drained conditions are expected at $V_{d r}$ or $V_{d r}^{\prime}<0.01$ to 0.1 and undrained condition at $V_{\text {un }}$ or $V^{\prime}$ un $>10$ to 100 (Lee \& Randolph 2011; DeJong \& Randolph 2012; Mahmoodzadeh \& Randolph 2014; Colreavy et al. 2016a), where the range reflects variations in the penetrometer and the choice of $c_{h}$ or $c_{v}$ in the definition of non-dimensional velocity. 
A different penetration resistance is observed under drained $\left(V^{\prime}<V_{d r}^{\prime}\right)$, partially drained $\left(V_{d r}^{\prime}\right.$ $\left.<V^{\prime}<V_{u n}^{\prime}\right)$ and undrained conditions $\left(V^{\prime}>V^{\prime}{ }_{u n}\right)$. Under drained conditions the soil has sufficient time to drain and consolidate. In contractile soils, an increase in $\mathrm{V}^{\prime}$ moves the response into the partially drained region, with a reduction in penetration resistance as less consolidation during penetration is possible. This results in a minimum penetration resistance at $V^{\prime}=V_{u n}^{\prime}$, beyond which the penetration resistance increases as positive viscous effects dominate over reductions in resistance associated with reduced drainage (Lehane et al. 2009).

The reduction in penetration resistance owing to changing drainage conditions is often described using a hyperbolic 'backbone curve' (Randolph \& Hope 2004), and the increase in penetration resistance due to viscous effects described using either a semi-logarithmic, inverse hyperbolic, power or Herschel-Bulkley relationship. Lehane et al. (2009) recognised that drainage and viscous effects should be considered in parallel. Hence the following expressions are used here to capture the combined response:

$$
\begin{aligned}
& \frac{q}{q_{u n, 0}}=\left[\frac{q_{d r} / q_{u n, 0}+\left(V^{\prime} / V_{50}^{\prime}\right)^{c}}{1+\left(V^{\prime} / V_{50}^{\prime}\right)^{c}}\right]\left[1+\mu\left[(v / d) /(v / d)_{r e f}\right]^{n}\right] \\
& \frac{q}{q_{r e f}}=\left[\frac{q_{d r} / q_{u n, 0}+\left(V^{\prime} / V_{50}^{\prime}\right)^{c}}{1+\left(V^{\prime} / V_{50}^{\prime}\right)^{c}}\right]\left[\frac{1+\mu\left[(v / d) /(v / d)_{r e f}\right]^{n}}{1+\mu}\right]
\end{aligned}
$$

where $q$ is the penetration resistance corresponding to $V^{\prime}$ or $v / d, q_{u n, 0}$ a reference undrained penetration resistance representing the very low strain rate levels associated with a laboratory element test, $q_{d r}$ the drained penetration resistance at $V^{\prime}=V_{d r}^{\prime}, V_{50}^{\prime}$ the non-dimensional velocity for $50 \%$ consolidation, $c$ a fitting coefficient, $(v / d)_{r e f}$ the reference strain rate, $\mu$ a viscous property and $n$ the shear-thinning index. Note that $q_{u n, 0}=q_{\text {ref }} /(1+\mu)$ where $q_{\text {ref }}$ is the reference penetration resistance corresponding to $(v / d)_{\text {ref. }}$ Hence Eq. 4a can also be presented in the equivalent form of Eq. $4 \mathrm{~b}$.

The first part of Eq. 4 accounts for consolidation effects, whereas the second part of Eq. 4 accounts for viscous rate effects using the Herschel-Bulkley formulation (as adopted by Zhu \& Randolph (2011)). The Herschel-Bulkley formulation originates from fluid mechanics, and is used here as it has the added benefit (relative to other strain rate formulations) of providing a minimum resistance at zero strain rate (Zhu \& Randolph 2011). At practical velocities (or strain rates) it provides similar strain-rate enhancement as a power law, as demonstrated later in the interpretation of free-fall piezocone tests (Eq. 5). 
In order to assess drainage and viscous rate effects on penetration resistance in the reconstituted calcareous silt, the following tests were conducted, covering seven orders of magnitude variation in $V^{\prime}$, in the range $V^{\prime}=0.01$ to $150000(v=0.001 \mathrm{~mm} / \mathrm{s}$ to $5 \mathrm{~m} / \mathrm{s})$ :

- Static monotonic or constant rate of penetration T-bar and piezocone tests $(v=0.003$, $0.01,0.06,0.1 \mathrm{~m} / \mathrm{s})$

- Free-fall piezocone test $\left(v_{i}=5 \mathrm{~m} / \mathrm{s}\right)$

- Twitch and 'breakthrough' T-bar and piezocone tests with initial penetration to $5 d$ under undrained conditions ( $V^{\prime}$ un) followed by 4 to 8 successive decreases in $v$ (and hence $V$ ), each with a penetration distance of $3 d$ (considered sufficient to achieve steady state conditions, Randolph \& Hope 2004), before breakthrough by returning to $V^{\prime}$ un for the last $3 d$ of penetration (House et al. 2001).

The twitch and breakthrough T-bar and piezocone penetrometer test sequences are illustrated in Fig. 9 and the corresponding net penetration resistance profiles shown in Fig. 10 and Fig. 11 for the T-bar and piezocone tests respectively. Also included in these figures are the reference undrained penetration tests that are temporally and spatially closest to the twitch tests. As shown in Fig. 10 and Fig. 11, a minimum $q_{T-b a r}$ and $q_{\text {net }}$ is observed at $v=0.3 \mathrm{~mm} / \mathrm{s}\left(V^{\prime} \sim 6\right)$ and $v=$ $3 \mathrm{~mm} / \mathrm{s}\left(V^{\prime} \sim 60\right)$ for the T-bar and piezocone respectively. Returning to the initial penetration velocity corresponding to $V^{\prime}$ un after a reduction in $V^{\prime}$ results in a higher breakthrough resistance, as discussed later.

To assess the combined response from consolidation and viscous effects, the T-bar and piezocone penetration resistance measured during the twitch and free-fall tests (discussed in detail later) is normalised by the reference undrained penetration resistance, $q_{\text {ref }}$ at $v_{\text {ref }}=0.003$ $\mathrm{m} / \mathrm{s}\left(V^{\prime}{ }_{r e f}=68\right.$ and 60 for T-bar and piezocone respectively using a depth averaged $\left.c_{v}\right)$. The normalised net penetration resistance, $q / q_{u n, 0}$ is plotted against $V^{\prime}$ in Fig. 12 together with Eq. 4a using the penetrometer diameter, $d=0.01 \mathrm{~m}$, a depth averaged $c_{h}=15.3 \mathrm{~m}^{2} / \mathrm{yr}$ and a reference velocity, $v_{\text {ref }}=0.003 \mathrm{~m} / \mathrm{s}$. Only penetration resistance data deeper than $z=5 d$ are included in Fig. 12 to avoid potential shallow embedment effects. The experimental data indicate that $V_{d r}^{\prime} \sim 0.02$ and $V^{\prime}{ }_{u n} \sim 60$ for the reconstituted calcareous silt (Fig. 12c), consistent with the range in $V_{d r}^{\prime}$ and $V_{u n}^{\prime}$ summarised earlier. The best fit to the experimental data using Eq. 4a was obtained using $q_{d r} / q_{u n, 0}=4.5, V_{50}^{\prime}=0.4, c=1.2, \mu=0.35, n=0.26$ and $(v / d)_{r e f}=$ $0.3 \mathrm{~s}^{-1}$. Fig. 12c also shows Eq. 4a as fitted to kaolin clay data reported by Randolph and Hope (2004) and Chow et al. (2017) using the parameters listed in Table 5. The kaolin parameters 
agree well with those adopted in previous studies that considered solely drainage effects, e.g. $V^{\prime}{ }_{50} \sim 1.2$ and $c=1.4$ for T-bar (Colreavy et al. 2016b) and piezocone variable rate tests (Mahmoodzadeh \& Randolph 2014). Comparison of the kaolin and calcareous silt curves on Fig. 12c shows that the $V^{\prime}$ limits for drained and undrained behaviour are broadly similar, although: (i) the ratio of $q_{d r} / q_{u n, 0}$ is approximately $40 \%$ higher in the calcareous silt, and (ii) strain rate effects are significantly more pronounced in the calcareous silt.

The respective contribution of the drainage and viscous rate effects are demonstrated in Fig. 12a and b respectively. The drainage component (left hand bracketed term in Eq. 4a) produces $q_{d r} / q_{u n, 0}=4.5$ at $V^{\prime}=0.001$ (i.e. at $V^{\prime} \leq V_{d r}^{\prime}$ ) and $q / q_{u n, 0}=1$ at $V^{\prime}=60$ (i.e. at $V^{\prime} \geq V^{\prime}{ }_{u n}$ ). The viscous component (right hand term in Eq. 4a) gives $q / q_{u n, 0}=1$ at $V^{\prime}=0$ (i.e. at $V^{\prime} \leq V_{d r}^{\prime}$ ) and $q_{\text {ref }} / q_{u n, 0}=1+\mu=1.35$ at $V^{\prime}=60$ (i.e. at $V^{\prime} \geq V^{\prime}{ }_{\text {un }}$ ). The $q_{\text {ref }} / q_{u n, 0}=1+\mu=1.35$ reflects the effects of strain rate at conventional penetration rates (typically $v / d \sim 0.5$ ) compared with a hypothetical 'undrained' penetration test at very low velocity. Interpretation of $q_{\text {ref }}$ in order to estimate undrained shear strengths equivalent to low strain rate laboratory element tests must also take account of compensating effects of partial remoulding and softening of the soil as it is sheared by the passing penetrometer (Zhou \& Randolph 2009). An implication for penetrometer testing in practice is that most field penetrometer testing in low permeability silty sands or clay will be 'very' undrained and far from the onset of partial consolidation. For instance, penetrating a $10 \mathrm{~cm}^{2}$ cone $(d=35.7 \mathrm{~mm})$ at the standard velocity, $v=20 \mathrm{~mm} / \mathrm{s}$ in this soil will result in a dimensionless velocity, $V^{\prime}=1484$, two orders of magnitude higher than required to measure the minimum undrained penetration resistance in soil with a similar consolidation coefficient.

Fig. 10 and Fig. 11 show the expected increase (for a contractile soil) in penetration resistance as the penetration velocity is reduced during a twitch test. In addition, Fig. 10 and Fig. 11 show that returning to the initial penetration velocity corresponding to $V^{\prime}{ }^{\prime}$ an after a reduction in $V^{\prime}$ results in a breakthrough resistance that is up to six times higher than the reference penetration resistance established in a separate test at $V^{\prime}$ un but without twitch stages. The increased breakthrough resistance is maintained for approximately $9 \mathrm{~d}$ for the T-bar, but is inconclusive for the piezocone as the actuator stroke was limited to an additional 3d penetration for these tests. The same effects are also measurable following the dissipation stage of an undrained penetration test, as discussed later. Similar breakthrough penetration resistance has been observed in other twitch tests (House et al. 2001; Schneider et al. 2004; Chung et al. 2006) and following piezocone and piezoball dissipation tests (e.g. Colreavy et al. 2016b) and load-hold 
stages during spudcan penetration tests (e.g. Erbrich 2005; Stanier et al. 2014; Bienen et al. 2015). The increase in resistance is attributed to locally decreased water content due to partial consolidation as $V^{\prime}$ decreases, resulting in stronger soil in a zone surrounding the penetrometer. This is consistent with the relatively lower breakthrough penetration resistance in Test T0.06T (Fig. 10), in which the twitch stages only reduced to $V^{\prime}=1530$, which remains within the undrained region dominated by viscous rate effects with little or no consolidation.

\section{Interpretation of free-fall piezocone tests}

The free-fall piezocone penetration resistance on Fig. 12 is evidently much higher than the static piezocone penetration resistance at $V^{\prime}=V^{\prime}$ un. Chow et al. (2017) described two approaches for interpreting free-fall piezocone data to produce profiles of penetration resistance that are equivalent to those measured in a static piezocone test at $V^{\prime}=V^{\prime}{ }_{u n}$.

The first approach - referred to as the 'accelerometer method' - equates the sum of the various forces acting on the piezocone during dynamic penetration in soil to the experimental net penetration resistance, taken as the product of the measured vertical acceleration and the piezocone mass. The second approach - referred to as the 'tip load cell method' - deduces the equivalent static penetration resistance from the tip load cell and $\mathrm{u}_{2}$ pore pressure measurements.

Both approaches require the deduced penetration resistance to be discounted for viscous strain rate effects (as shown by Fig. 12), and for drag resistance, which can be significant at shallow embedment in low strength sediments and at high penetration velocity. Further consideration is required for the accelerometer method to estimate the shaft resistance at high strain rates. Chow et al. (2017) showed that the tip load cell method produced profiles of strength resistance in kaolin clay that were within $10 \%$ of those established from static piezocone tests, whereas the accelerometer method resulted in profiles that varied from the static profiles by up to $75 \%$. This experience is extended by applying both methods to the free-fall piezocone tests in the calcareous silt considered here.

In order to produce similar penetration resistance as measured in a static piezocone test, viscous rate effects need to be accounted for properly. Fig. 13 provides profiles of net penetration resistance, $q_{\text {net }}$, sleeve friction, $f_{s}$ and excess pore pressure, $\Delta u_{2}$ during a free-fall piezocone test (Test D5D) together with equivalent measurements from static piezocone tests with $v / d \geq$ $(v / d)_{\text {ref }}$ covering $v=0.003,0.01$ and $0.1 \mathrm{~m} / \mathrm{s}$. As the lowest penetration velocity corresponds to 
$v / d=0.3 \mathrm{~s}^{-1}$ and $V^{\prime}=60, q_{\text {net }}$ and $f_{\mathrm{s}}$ are expected to increase with increasing velocity, as demonstrated by Fig. 13. Negative excess pore pressures, $\Delta u_{2}$, were measured in both the freefall and static piezocone tests, becoming positive at different depths in the static tests. There is no discernible dependence on penetration velocity, unlike observations made from tests in kaolin clay, where negative $\Delta u_{2}$ was associated only with relatively high penetration velocities (Chow et al. 2014, 2017).

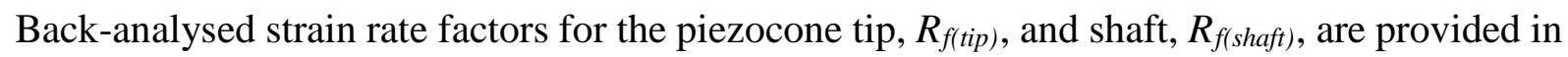
Fig. 14, calculated using both the Herschel-Bulkley relationship (right hand term in Eq. 4) and power law expressions

$$
\begin{aligned}
& R_{f(\text { tip })}=\frac{q_{\text {net }}}{q_{\text {net }, \text { ref }}}=\left(\frac{(v / d)}{(v / d)_{\text {ref }}}\right)^{\beta_{\text {tip }}} \geq 1 \\
& R_{f(\text { shaft })}=\frac{f_{s}}{f_{s, r e f}}=\left(\frac{(v / d)}{(v / d)_{\text {ref }}}\right)^{\beta_{\text {shaft }}} \geq 1
\end{aligned}
$$

to provide context with published experience. $\beta_{\text {tip }}$ and $\beta_{\text {shaft }}$ in Eq. 5 are strain rate parameters for the tip and shaft resistance respectively. In both the Herschel-Bulkley and the power formulations, $(v / d)_{\text {ref }}=0.3 \mathrm{~s}^{-1}$. As expected from Fig. 12, the best fit with the piezocone tip data using the Herschel-Bulkley equation is obtained using $\mu=0.35$ and $n=0.26$. The power law (Eq. 5) best fits the piezocone tip data using $\beta_{\text {tip }}=0.125$, which is approximately twice the value commonly reported for kaolin clay and other reconstituted natural clays (Chow et al. 2017; Morton et al. 2016; O’Beirne et al. 2017), but similar to previous experience in reconstituted calcareous silts: $\beta_{\text {tip }}=0.16$ (variable penetration rate T-bar tests, Boukpeti \& White 2011) and $\beta_{\text {tip }}=\beta_{\text {shaft }}=0.14$ to 0.16 (dynamically installed anchors). Fig. 14 also shows that the viscous rate effect in this soil is higher for shaft resistance $\left(\beta_{\text {shaft }}=0.15\right)$ than tip resistance $\left(\beta_{\text {tip }}=0.125\right)$. The corresponding ratio, $R_{f(\text { shaft })} / R_{f(t i p)}$ ranges from 1 to 1.2 over the range of penetration velocities in the free-fall piezocone tests $(v \leq 8 \mathrm{~m} / \mathrm{s})$, so much lower than the corresponding range of 1 to 3.9 over the same range of penetration velocities in kaolin clay (Chow et al. 2017).

With $R_{f(t i p)}$ and $R_{f(\text { shaft })}$ established, a comparison can now be made between the net penetration resistance, $q_{\text {net }}$ of the static and free-fall piezocone tests following the procedure described in Chow et al. (2017). The performance of both the tip load cell method and the accelerometer method is assessed in Fig. 15, which compares $q_{\text {net }}$ profiles for the static and free-fall piezocone 
tests, where the latter are made equivalent to the static test by accounting for strain rate effects and drag resistance. The tip load cell method (shown for test D5D only due to a faulty $u_{2}$ pore pressure sensor in the remaining free-fall tests) is seen to produce much better agreement with the static $q_{\text {net }}$ profile than the accelerometer method (shown for tests D1, D5 and D5D), with $q_{\text {net }}$ over-predicted by up to $\sim 50 \%$. This is consistent with the experience for these prediction methods in kaolin clay (Chow et al. 2017), and is attributed to the difficulty in quantifying dynamic shaft resistance even when using a back-analysed strain rate parameter for shaft resistance.

\section{DISCUSSION}

The range in penetration resistance measurable in penetrometer testing is summarised in Fig. 16 , which indicates that for a given depth the resistance may vary by a factor of $>20$ depending on the penetrometer test or test stage. The lowest penetration resistance is that measured in the cyclic remoulding T-bar test, which provides the remoulded undrained penetration resistance. The highest penetration resistance is the breakthrough resistance when the penetration velocity switches from drained to undrained and the penetrometer is moving through a zone of 'improved' (consolidated) soil at the end of a twitch test. There are sparse examples in the literature that such variations in penetration resistance will also be realised in situ, although the effects will be less pronounced in over consolidated soils.

Reductions in penetration resistance due to remoulding are well documented via examples of cyclic T-bar and piezoball tests (e.g. Erbrich 2005; Boylan et al. 2007; Low et al. 2008; Yafrate et al. 2009; Kelly et al. 2014). Systematic studies of increases in penetration resistance due to partial drainage during penetration are less common as this requires the penetration rate to be varied in order for the effect to be demonstrated. Examples from the field are mainly from research studies, such as those reported in Chung et al. (2006) and Colreavy et al. (2016a), although the effect of partial drainage on penetration resistance of penetrometers and spudcan foundation in intermediate (silt and silty sand) calcareous sediments has been discussed in detail by Erbrich (2005).

Increases in penetration resistance following dissipation tests are more widely documented, and can be significant. For example, an increase in piezoball net resistance of approximately $46 \%$ was observed in Ballina clay (New South Wales, Australia) following a dissipation test, with a $147 \%$ increase after a twitch test that involved reduction in the penetration velocity from 20 $\mathrm{mm} / \mathrm{s}$ to $0.02 \mathrm{~mm} / \mathrm{s}$, allowing time to pass and dissipation to occur (Colreavy et al. 2016a). 
The different penetration resistances shown on Fig. 16 may either be adjusted to provide a nominally undrained penetration resistance or be converted to a soil strength that can be applied directly in design. For example the dynamic $q_{\text {net }}$ measured in a free-fall piezocone test may be 'converted' to the equivalent static piezocone $q_{\text {net,ref }}$ (as demonstrated in the free-fall piezocone interpretation section); twitch and dissipation stages can be included in a penetrometer test to check $V^{\prime}$, adjusting using Eq. 4 if necessary to obtain the relevant undrained $q_{\text {net,ref }}$. Alternatively the penetration resistance may be converted to a strength using an appropriate capacity factor for application in design. For example, the remoulded undrained strength measured in a cyclic remoulding test can be used as a direct input in calculations of pipeline embedment, and the consolidated undrained strength measured in a post-dissipation penetration test can be used to quantify the available soil strength following a post-installation period for a subsea foundation or pipeline.

\section{CONCLUSIONS}

Extending test protocols in penetrometer tests offers an opportunity to measure a wider range of soil properties that are applicable to offshore geotechnical design, including both intact and remoulded soil strength, post consolidation soil strength and the coefficient of consolidation. These novel test protocols also allow drainage and viscous strain rate effects to be quantified during penetration, and adjusted where required to obtain a nominally undrained penetration resistance. Previous studies have assessed this opportunity in kaolin clay and this experience has been extended here by considering a reconstituted calcareous silt.

The penetrometer tests were conducted in a geotechnical centrifuge using model scale T-bar and piezocone penetrometers that were either penetrated statically at varying velocities, or (in the case of the piezocone) were installed by free-fall. The results, which span over seven orders of magnitude variation in penetration velocity, demonstrate that the measured resistance can vary by a factor of $>20$ (Fig. 16). The variation in penetration resistance for different testing conditions reflects the differing soil strengths that can be mobilised. For instance the remoulded undrained shear strength that can be determined from a cyclic remoulding T-bar or ball penetration test controls pipeline embedment, whereas the consolidated undrained shear strength that can be deduced from post-dissipation penetration is the soil strength that would be available following a post-installation period for a pipeline or subsea foundation. These values can be used directly in design or the values can be adjusted to account for drainage and viscous strain rate effects, to obtain the relevant undrained penetration resistance. Much of the variation 
can be described using a simple equation that couples drainage and viscous strain rate effects, allowing the resistance measured in a penetrometer test to be assessed for these effects and adjusted if required.

The viscous strain rate effect was much stronger in the calcareous silt considered here than is reported from similar tests in non-calcareous fine-grained soils. The strain rate effects were broadly similar for tip and shaft resistance, and were consistent between variable rate static penetrometer tests and free-fall tests, as captured by both the Herschel-Bulkley and power law formulations. Although the effects are even higher for a free-fall piezocone test (and include drag resistance), they can be readily quantified such that the discounted net penetration resistance is within $10 \%$ of that measured in a static piezocone test.

It should also be emphasised that the relative effects of consolidation and strain rate are very different at model and field scale, because of the larger penetrometer diameter and penetration rate (hence much larger $v_{r e f} d_{e} / c_{h}$ value) for the latter. For a typical field scale piezocone penetrated at the standard $20 \mathrm{~mm} / \mathrm{s}$, the $V^{\prime}$ value may be one or two orders of magnitude greater than $V^{\prime}$ un, resulting in penetration resistance that lies significantly above the minimum value that might be obtained at lower penetration rates with $V^{\prime} \sim V^{\prime}{ }_{\text {un }}$. Care is needed in choosing an appropriate undrained penetration resistance, and shear strength, for application in the design of foundations that are several orders of magnitude larger than even a field-scale penetrometer, but where the strain rate will typically be considerably lower.

\section{ACKNOWLEDGEMENTS}

This work forms part of the activities of the Centre for Offshore Foundation Systems (COFS), currently supported as a node of the Australian Research Council's Centre of Excellence for Geotechnical Science and Engineering, and through the Fugro Chair in Geotechnics, the Lloyd's Register Foundation Chair and Centre of Excellence in Offshore Foundations and the Shell EMI Chair in Offshore Engineering. The work is funded by the Remote Intelligent Geotechnical Seabed Surveys (RIGSS) Joint Industry Project, which is currently supported by Fugro, Shell, Total and Woodside.

\section{NOTATION}

$\begin{array}{ll}c & \text { Fitting coefficient in Eq. (4) } \\ \text { CaCO3 } & \text { Carbonate content } \\ C_{D} & \text { Drag coefficient }\end{array}$




\begin{tabular}{|c|c|}
\hline 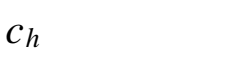 & Coefficient of horizontal consolidation, \\
\hline$c_{v}$ & Coefficient of vertical consolidation \\
\hline$d$ & Penetrometer diameter \\
\hline$d_{e}$ & Diameter of a circle with the same projected area as the penetrometer \\
\hline$d_{50}$ & Mean particle size \\
\hline$e$ & Void ratio \\
\hline FFP & Free-fall piezocone \\
\hline$f_{s}$ & Sleeve friction \\
\hline G & Elastic shear modulus \\
\hline$G_{s}$ & Specific gravity \\
\hline$I_{r}$ & Rigidity index \\
\hline$k$ & Permeability \\
\hline$L$ & Penetrometer length \\
\hline LL & Liquid limit \\
\hline$M$ & Critical state frictional constant \\
\hline$n$ & Shear thinning index in Herschel-Bulkley relationship \\
\hline$n_{\text {tip }}, n_{\text {shaft }}$ & Shear thinning index for tip and shaft resistance respectively \\
\hline$N_{\text {T-bar }}$ & T-bar capacity factor \\
\hline$p^{\prime}$ & Mean effective stress \\
\hline PSD & Particle size distribution \\
\hline PL & Plastic limit \\
\hline$q$ & Penetration resistance \\
\hline$q_{d r}$ & Drained penetration resistance at $V^{\prime}=V^{\prime} \mathrm{dr}$ \\
\hline$q_{\text {int }}$ & Intact penetration resistance \\
\hline$q_{\text {net }}$ & Piezocone net resistance \\
\hline$q_{\text {ref }}$ & Reference penetration resistance corresponding to $(v / d)_{\text {ref }}$ \\
\hline$q_{T-b a r}$ & T-bar net penetration resistance \\
\hline$q_{u n, 0}$ & Penetration resistance at very low or zero strain rate \\
\hline$R$ & Penetrometer radius \\
\hline$R_{f(t i p),}, R_{f(\text { shaft })}$ & Strain rate factors for piezocone tip and shaft resistance respectively \\
\hline$S_{t}$ & Sensitivity \\
\hline$s_{u}$ & Undrained shear strength \\
\hline$T^{*}$ & Modified time factor \\
\hline$t$ & Time \\
\hline
\end{tabular}




\begin{tabular}{|c|c|}
\hline USCS & Unified Soil Classification System \\
\hline UWA & University of Western Australia \\
\hline$u_{2}$ & Pore pressure measured at cone shoulder \\
\hline$\Delta u_{2}$ & Excess pore pressure, $u_{2}-u_{\mathrm{f}}$ \\
\hline$\Delta u_{i}$ & Initial excess pore pressure, $u_{\mathrm{i}}-u_{\mathrm{f}}$ \\
\hline$u_{f}$ & Final pore pressure at the end of dissipation \\
\hline$u_{i}$ & Initial pore pressure at the beginning of dissipation \\
\hline$v$ & Penetration velocity \\
\hline$V, V^{\prime}$ & Non-dimensional velocity \\
\hline$V_{d r}, V^{\prime} d r$ & Drained non-dimensional velocity \\
\hline$V_{\text {un }}, V_{\text {un }}^{\prime}$ & Undrained non-dimensional velocity \\
\hline$V_{50}^{\prime}$ & Non-dimensional velocity for $50 \%$ consolidation \\
\hline$v$, vref & Penetration velocity, reference velocity \\
\hline$v_{i}$ & Impact velocity \\
\hline$z$ & Prototype penetration depth \\
\hline$\alpha$ & Interface friction ratio \\
\hline$\alpha_{\text {cone }}$ & Unequal area ratio \\
\hline$\beta_{\text {tip }}, \beta_{\text {shaft }}$ & Power-law strain rate parameters for tip and shaft resistance respectively \\
\hline$\gamma^{\prime}$ & Effective unit weight \\
\hline$\delta_{\text {rem }}$ & Ratio of fully remoulded and initial penetration resistance \\
\hline$\xi$ & Average magnitude of accumulated soil plastic shear strain \\
\hline$\xi_{95}$ & The value of $\xi$ required for $95 \%$ remoulding \\
\hline$\kappa$ & Slope of swelling line \\
\hline$\lambda$ & Slope of normal compression line \\
\hline$\mu$ & Viscous property in Herschel-Bulkley relationship \\
\hline$v$ & Poisson’s ratio \\
\hline$\sigma_{v}^{\prime}$ & Vertical effective stress \\
\hline$\phi_{C S}$ & Critical state friction angle \\
\hline
\end{tabular}

\section{REFERENCES}

ASTM (2012). ASTM D5778 Standard test method for performing electronic friction cone and piezocone penetration testing of soils. American Society for Testing and Materials, West Conshohocken, Pennsylvania, USA. 
Bienen, B., Ragni, R., Cassidy, M.J., \& Stanier, S.A. (2015). Effects of consolidation under a penetrating footing in carbonate silty clay. Journal of Geotechnical and Geoenvironmental Engineering, 141(9), 04015040-1 to 04015040-10.

Boukpeti, N. \& White, D.J. (2011). Strength characterisation of a carbonate silt across the solid-fluid boundary. MERIWA project Report 11549, Centre for Offshore Foundation Systems, the University of Western Auslitra.

Boylan, N., Long, M., Ward, D., Barwise, A. \& Georgious, B. (2007). Full-flow penetrometer testing in Bothkennar clay. In Proceedings of the 6th international offshore site investigation and geotechnics conference: confronting new challenges and sharing knowledge, pp. 177-186. London, UK: Society for Underwater Technology.

Chai, J., Sheng, D., Carter, J. P., \& Zhu, H. (2012). Coefficient of consolidation from nonstandard piezocone dissipation curves. Computers and Geotechnics, 41, 13-22

Chow, S. H., O’Loughlin, C. D., \& Randolph, M. F. (2014). Soil strength estimation and pore pressure dissipation for free-fall piezocone in soft clay. Geotechnique, 64(10), 817-827.

Chow, S. H., O’Loughlin, C. D., White, D. J. \& Randolph, M. F. (2017). An extended interpretation of the free-fall piezocone test in clay. Géotechnique, 67(12),1090-1103.

Chung, S. F. \& Randolph, M. F. (2004). Penetration resistance in soft clay for different shaped penetrometers. Proceedings of the 2nd International Conference on Site Characterisation, Porto, pp 671-677.

Chung, S. F., Randolph, M. F., \& Schneider, J. A. (2006). Effect of penetration rate on penetrometer resistance in clay. Journal of Geotechnical and Geoenvironmental Engineering, 132(9), 1188-1196.

Colreavy, C., O’Loughlin, C. D., \& Randolph, M. F. (2016a). Estimating consolidation parameters from field piezoball tests. Geotechnique, 66(4), 333-343.

Colreavy, C., O’Loughlin, C. D., \& Randolph, M. F. (2016b). Experience with a dual pore pressure element piezoball. International Journal of Physical Modelling in Geotechnics, 16(3), 101-118.

DeJong, J. T., \& Randolph, M. F. (2012). Influence of partial consolidation during cone penetration on estimated soil behavior type and pore pressure dissipation measurements. Journal of Geotechnical and Geoenvironmental Engineering, 138(7), 777-788.

DeJong, J., Yafrate, N., DeGroot, D., Low, H. E., \& Randolph, M. (2010). Recommended practice for full-flow penetrometer testing and analysis. Geotechnical Testing Journal, 33(2), 137-149.

Dutt, R. N., \& Ingram, W. B. (1990). Discussion: Classification of Marine Sediment. Journal of Geotechnical Engineering, 116(8), 1288-1289.

Einav, I., \& Randolph, M. F. (2005). Combining upper bound and strain path methods for evaluating penetration resistance. International Journal for Numerical Methods in Engineering, 63(14), 1991-2016.

Erbrich, C. (2005). Australian frontiers-spudcans on the edge. Proceedings of International Symosium on Frontiers in Offshore Geotechnics: ISFOG, pp. 49-74.

Erbrich, C., \& Hefer, P. (2002). Installation of the Laminaria Suction Piles: A Case History. Proceedings of Offshore Technology Conference (OTC), (14240-MS).

Finnie, I. M. S., \& Randolph, M. F. (1994). Punch-through and liquefaction induced failure of 
shallow foundations on calcareous sediments. Proceedings of International Conference on Behaviour of Offshore Structures, Boston, MA., pp. 217 - 230.

House, A. R., Oliveira, J. R. M. S., \& Randolph, M. F. (2001). Evaluating The Coefficient Of Consolidation Using Penetration Tests. International Journal of Physical Modelling in Geotechnics, 1(3), 17-25.

International Organization for Standardization (2014). Petroleum and natural gas industries Specific requirements for offshore structures - Part 8: Marine soil investigations (ISO 19901-8:2014).

Jewell, R.J. \& Khorshid, M.S. (1988). Engineering for Calcareous Sediments, International Conference on Calcareous Sediments, Perth, Balkema.

Kelly, R. B., O’Loughlin, C. D., Bates, L., Gourvenec, S. M., Colreavy, C., White, D. J., Gaone, F. M., Doherty, J. P. \& Randolph, M. F. (2014). In situ testing at the National Soft Soil Field Testing Facility, Ballina, New South Wales. Australian Geomechnics Journal. 49(4), $15-28$.

Koh, K. X., Hossain, M. S., \& Kim, Y. (2017). Installation and Monotonic Pullout of a Suction Caisson Anchor in Calcareous Silt. Journal of Geotechnical and Geoenvironmental Engineering, 143(2): 04016098.

Lee, J., \& Randolph, M. (2011). Penetrometer-Based Assessment of Spudcan Penetration Resistance. Journal of Geotechnical and Geoenvironmental Engineering, 137(6), 587596.

Lehane, B. M., O’Loughlin, C. D., Gaudin, C., \& Randolph, M. F. (2009). Rate effects on penetrometer resistance in kaolin. Geotechnique, 59(1), 41-52.

Low, H. E., Randolph, M. F., DeJong, J. T. \& Yafrate, N. J. (2008). Variable rate full-flow penetration tests in intact and remoulded soil. In Proceedings of the 3rd international conference on geotechnical and geophysical site characterisation - ISC 3 (eds A.-B. Huang and P. W. Mayne), pp. 1087-1092. London, UK: Taylor \& Francis.

Low, H. E., Lunne, T., Andersen, K. H., Sjursen, M. A., Li, X., \& Randolph, M. (2010). Estimation of intact and remoulded undrained shear strengths from penetration tests in soft clays. Geotechnique, 60(11), 843-859.

Lunne, T., Andersen, K. H., Low, H. E., \& Randolph, M. F. (2011). Guidelines for offshore in situ testing and interpretation in deepwater soft clays. Canadian Geotechnical Journal, 48, 543-556.

Mahmoodzadeh, H., \& Randolph, M. (2014). Penetrometer Testing: Effect of Partial Consolidation on Subsequent Dissipation Response. Journal of Geotechnical and Geoenvironmental Engineering, 140(6), 04014022.

Mahmoodzadeh, H., Wang, D., \& Randolph, M. F. (2015). Interpretation of piezoball dissipation testing in clay. Géotechnique, 65(10), 831-842.

Mao, X., \& Fahey, M. (2003). Behaviour of calcareous soils in undrained cyclic simple shear. Géotechnique, 53(8), 715-727.

Mao, X. (2000). The bahaviour of three alcareous soils in monotonic and cyclic loading. PhD thesis, The University of Western Australia, Crawley, Australia.

Morton, J. P., O’Loughlin, C. D., \& White, D. J. (2016). Centrifuge modelling of an instrumented free-fall sphere for measurement of undrained strength, Canadian Geotechnical Journal, 53(6), 918-929, doi: 10.1139/cgj-2015-0242. 
O’Beirne, C., O’Loughlin, C.D., \& Gaudin, C. (2017). Assessing penetration resistance on dynamically installed anchors, Canadian Geotechnical Journal, 54(1), 1-17.

Randolph, M. F., \& Hope, S. (2004). Effect of cone velocity on cone resistance and excess pore pressures. Proceedings of the International Symposium on Deformation Characteristics of Geomaterials - IS Osaka. The Hague, The Netherlands, pp. 147-152.

Randolph, M. F., Low, H. E., \& Zhou, H. (2007). In situ testing for design of pipeline and anchoring systems. Proceedings of the 6th International Conference on Offshore Site Investigation and Geotechnics: Confronting New Challenges and Sharing Knowledge London, UK., pp. 251-262.

Sahdi, F., White, D. J., Gaudin, C., Randolph, M. F., \& Boylan, N. (2016). Laboratory development of a vertically oriented penetrometer for shallow seabed characterization. Canadian Geotechnical Journal, 102, 93-102.

Schneider, J. A., Randolph, M. F., \& Chung, S. F., (2004). Characterization of soft soils for deep water developments. Report Geo:03305, Centre for Offshore Foundation Systems, The University of Western Australia, Crawley, Australia.

Stanier, S. A., Ragni, R., Bienen, B., \& Cassidy, M. J. (2014). Observing the effects of sustained loading on spudcan footings in clay. Geotechnique, 64(11), 918-929.

Stewart, D. P. (1992). Lateral loading of piled bridge abutments due to embankment construction. PhD thesis, The University of Western Australia, Crawley, Australia.

Sully, J. P., Robertson, P. K., Campanella, R. G. \& Woeller, D. J. (1999). An approach to evaluation of field CPTU dissipation data in overconsolidated fine-grained soils. Canadian Geotechnical Journal, 36 (2), 369-381.

Teh, C. I., \& Houlsby, G. T. (1991). An analytical study of the cone penetration test in clay. Geotechnique, 41(1), 17-34.

Walker, B. F., \& Clark, A. R. (1977). A proposed scheme for the classification and nomemclature for use in the engineering description on Middle Eastern sedimentary rocks. Géotechnique, 27(1), 93-99.

Yafrate, N. J., DeJong, J. T., DeGroot, D. \& Randolph, M. (2009). Evaluation of remolded shear strength and sensitivity of soft clay using full-flow penetrometers. Journal of Geotechnical and Geoenvironmental Engineering, 135(9), 1179-1189.

Yuan, F., White, D.J. \& O’Loughlin, C.D. (2017). The evolution of seabed stiffness during cyclic movement in a riser touchdown zone on soft clay. Géotechnique, 67(2), 127-137.

Zhou, H. and Randolph, M.F. (2009). Resistance of full-flow penetrometers in rate-dependent and strain-softening clay. Géotechnique, 59(2), 79-86.

Zhu, H., \& Randolph, M. F. (2011). Numerical analysis of a cylinder moving through ratedependent undrained soil. Ocean Engineering, 38(7), 943-953. 


\section{LIST OF TABLES}

Table 1: Properties of calcareous silt

Table 2: Model penetrometer details

Table 3: Centrifuge test program

Table 4: Strain softening parameters established from T-bar tests

Table 5: Backbone curve and viscous rate parameters 


\section{LIST OF FIGURES}

Fig. 1: Map of different soil tests and design cases (extended from Randolph et al. 2007)

Fig. 2: Comparison of particle size distributions of various natural calcareous soils

Fig. 3: Model penetrometers used in the centrifuge tests: (a) piezocone; and (b) T-bar

Fig. 4: Static and free-fall penetration test setup in the centrifuge

Fig. 5: Penetration resistance profiles obtained from static penetrometer tests

Fig. 6: Normalised cyclic degradation curves established from T-bar cyclic tests

Fig. 7: Dissipation curves from static and free-fall piezocone tests

Fig. 8: Interpreted coefficient of consolidation for calcareous silt

Fig. 9: Twitch test program for T-bar and piezocone

Fig. 10: Penetration resistance profiles of T-bar twitch tests

Fig. 11: Net penetration resistance profiles of piezocone twitch tests

Fig. 12: Backbone curve derived from the various penetrometer tests: (a) consolidation effects;

(b) viscous rate effects; and (c) combined response from consolidation and viscous effects

Fig. 13: Rate effects in piezocone tests: (a) net tip resistance; (b) sleeve friction; (c) excess pore pressure

Fig. 14: Back-analysed strain rate parameters for free-fall piezocone test D5D $\left(v_{i}=4.7 \mathrm{~m} / \mathrm{s}\right)$ :

(a) net tip resistance; (b) sleeve friction

Fig. 15: Comparison between the static and free-fall piezocone net penetration resistance using:

(a) tip load cell (LC) method; (b) accelerometer (Acc) method

Fig. 16: Penetration resistances measured in different penetrometer tests or test stages 
Table 1: Properties of calcareous silt

\begin{tabular}{|c|c|c|c|c|c|}
\hline Soil Properties & $\begin{array}{l}\text { Calcareous } \\
\text { Silt (this } \\
\text { study) }\end{array}$ & $\begin{array}{c}\text { Gorgon } \\
\text { muddy silt } \\
\text { (Mao 2000) }\end{array}$ & $\begin{array}{c}\text { Gorgon } \\
\text { seabed silt } \\
\text { (Mao 2000) }\end{array}$ & $\begin{array}{c}\text { Laminaria } \\
\text { silty clay } \\
\text { (Erbrich \& } \\
\text { Hefer 2002) }\end{array}$ & $\begin{array}{l}\text { UWA } \\
\text { kaolin clay } \\
\text { (Stewart } \\
\text { 1992) }\end{array}$ \\
\hline Liquid limit, LL (\%) & 67 & $40-50$ & - & $51-74$ & 61 \\
\hline Plastic limit, PL (\%) & 39 & 30 & - & $29-34$ & 27 \\
\hline Specific gravity, $G_{s}$ & 2.71 & $2.7-2.9$ & 2.77 & 2.69 & 2.60 \\
\hline $\begin{array}{l}\text { Mean diameter, } d_{50} \\
(\mathrm{~mm})\end{array}$ & $\begin{array}{l}\sim 001 \\
\sim 0.001\end{array}$ & 0.0015 & 0.024 & $0.005-0.017$ & - \\
\hline $\begin{array}{l}\text { Carbonate content, } \\
\text { CaCO3 (\%) }\end{array}$ & 73.29 & 95 & - & 70 & 0 \\
\hline Organic content (\%) & 0.97 & - & - & - & 0 \\
\hline $\begin{array}{c}\text { Critical state friction } \\
\text { angle, } \phi_{c S}\left({ }^{\circ}\right)\end{array}$ & 40 & 42 & 41 & - & 23 \\
\hline $\begin{array}{c}\text { Critical state frictional } \\
\text { constant, } M\end{array}$ & 1.62 & 1.72 & 1.67 & - & 0.92 \\
\hline $\begin{array}{l}\text { Void ratio at } p^{\prime}=1 \mathrm{kPa} \\
\text { on critical state line, } \Gamma\end{array}$ & - & - & - & - & 2.14 \\
\hline $\begin{array}{c}\text { Slope of normal } \\
\text { consolidation line, } \lambda\end{array}$ & 0.287 & 0.2 & - & - & 0.205 \\
\hline Slope of swelling line, $\kappa$ & 0.036 & - & - & - & 0.044 \\
\hline $\begin{array}{l}\text { Coefficient of vertical } \\
\text { consolidation, } c_{v}\left(\mathrm{~m}^{2} / \mathrm{yr}\right)\end{array}$ & $\begin{array}{c}8.9\left(\sigma_{v}^{\prime}=40\right. \\
\left.\mathrm{kPa}^{1}\right)\end{array}$ & - & - & 2 to 30 & $\begin{array}{l}2.6\left(\sigma_{v}^{\prime}=\right. \\
\left.40 \mathrm{kPa}^{1}\right)\end{array}$ \\
\hline Permeability, $k(\mathrm{~m} / \mathrm{s})$ & $\begin{array}{c}1.64 \times 10^{-9} \\
\left(\sigma^{\prime}=40\right. \\
\left.\mathrm{kPa}^{1}\right)\end{array}$ & - & - & $\begin{array}{c}2 \times 10^{-9} \\
\text { (mudline) to } 4 \\
\times 10^{-10}(60 \mathrm{~m})\end{array}$ & $\begin{array}{c}1.8 \times 10^{-9} \\
\left(\sigma_{v}^{\prime}=40\right. \\
\left.\mathrm{kPa}^{1}\right)\end{array}$ \\
\hline
\end{tabular}

Note: ${ }^{1}$ approximate stress level at mid sample height 
Table 2: Model penetrometer details

\begin{tabular}{|c|c|c|}
\hline & T-bar & Piezocone (static and free-fall) \\
\hline Dimension & $\begin{array}{c}d=5 \mathrm{~mm} \\
L=20 \mathrm{~mm}\end{array}$ & $\begin{array}{c}d=10 \mathrm{~mm} \\
L=120 \mathrm{~mm}\end{array}$ \\
\hline Mass & - & $29 \mathrm{~g}$ \\
\hline Instrumentation & - $\quad$ Tip load cell & $\begin{array}{l}\text { - } \quad \text { Tip load cell } \\
\text { - Shaft load cell } \\
\text { - } \quad \text { Pore pressure transducer at cone shoulder, } \mathrm{u}_{2} \text { position } \\
\text { - } \quad \text { single-axis accelerometer }\end{array}$ \\
\hline
\end{tabular}

Table 3: Centrifuge test program

\begin{tabular}{|c|c|c|c|}
\hline Penetrometer & \multicolumn{2}{|c|}{ Test ID* \& Type } & Penetration rate or impact velocity $(\mathrm{m} / \mathrm{s})$ \\
\hline \multirow{6}{*}{$\begin{array}{l}\text { Piezocone } \\
\text { (static) }\end{array}$} & S0.003D & Dissipation & 0.003 \\
\hline & S0.003M & Monotonic & 0.003 \\
\hline & S0.003T1 & Twitch & $(3,1,0.3,0.1,3) \times 10^{-3}$ \\
\hline & S0.003T2 & Twitch & $(3,0.03,0.01,0.001,3) \times 10^{-3}$ \\
\hline & $\mathrm{S} 0.01 \mathrm{M}$ & Monotonic & 0.01 \\
\hline & S0.1D & $\begin{array}{c}\text { Monotonic \& } \\
\text { Dissipation }\end{array}$ & 0.1 \\
\hline \multirow{3}{*}{$\begin{array}{l}\text { Piezocone } \\
\text { (free-fall) }\end{array}$} & D1 & Free-fall & 0.9 \\
\hline & D5 & Free-fall & 5.4 \\
\hline & D5D & $\begin{array}{l}\text { Free-fall \& } \\
\text { Dissipation }\end{array}$ & 4.7 \\
\hline \multirow[t]{5}{*}{ T-bar } & T0.003C1 & Cyclic & 0.003 \\
\hline & T0.003C2 & Cyclic & 0.003 \\
\hline & T0.003T & Twitch & $(3,0.3,0.1,0.03,0.01,0.003,0.001,3) \times 10^{-3}$ \\
\hline & T0.06M & Monotonic & 0.06 \\
\hline & $\mathrm{T} 0.06 \mathrm{~T}$ & Twitch & $(60,20,6,2,0.6,60) \times 10^{-3}$ \\
\hline
\end{tabular}

Table 4: Strain softening parameters established from T-bar tests

\begin{tabular}{|c|c|c|c|c|}
\hline Soil & Test ID & $\begin{array}{c}\text { Sensitivity, } \\
S_{t}\end{array}$ & $\delta_{\text {rem }}$ & $\xi_{95}$ \\
\hline \multirow{2}{*}{ Calcareous silt } & T0.003C1 & 3.77 & 0.26 & 6.9 \\
\cline { 2 - 5 } & T0.003C2 & 4.64 & 0.22 & 6.5 \\
\hline Kaolin (Sahdi et al. 2016) & - & 2.5 & 0.4 & 5.8 \\
\hline
\end{tabular}


Table 5: Backbone curve and viscous rate parameters

\begin{tabular}{|c|c|c|c|c|c|c|c|c|c|c|}
\hline \multirow[t]{2}{*}{ Reference } & \multirow[t]{2}{*}{ Penetrometer } & \multirow[t]{2}{*}{ Soil } & \multicolumn{3}{|c|}{$\begin{array}{l}\text { Rate parameters for } \\
\text { partial drainage }\end{array}$} & \multicolumn{4}{|c|}{$\begin{array}{c}\text { Rate parameters for viscous } \\
\text { behaviour }\end{array}$} & \multirow[t]{2}{*}{$V_{d r}^{\prime}$ and $V_{u n}^{\prime}$} \\
\hline & & & $q_{d r} / q_{u n, 0}$ & $V_{50}^{\prime}$ & C & $\begin{array}{l}q_{\text {ref }} / q_{\text {un }, 0} \\
=1+\mu\end{array}$ & $\mu$ & $n$ & $(v / d)_{r e f}$ & \\
\hline This study & $\begin{array}{c}\text { Piezocone \& } \\
\text { T-bar }\end{array}$ & $\begin{array}{l}\text { Calcareous } \\
\text { silt }\end{array}$ & 4.5 & 0.4 & 1.2 & 1.35 & 0.35 & 0.26 & 0.3 & $V_{d r}^{\prime}<0.02, V_{\text {un }}^{\prime}>60$ \\
\hline $\begin{array}{l}\text { Randolph \& Hope } \\
\text { (2004); Chow et al. } \\
\text { (2017) }\end{array}$ & $\begin{array}{l}\text { Piezocone \& } \\
\text { T-bar }\end{array}$ & Kaolin clay & 3.2 & 0.4 & 1 & 1.35 & 0.35 & 0.10 & 0.1 & $V_{d r}^{\prime}<0.1, V_{u n}^{\prime}>60$ \\
\hline
\end{tabular}




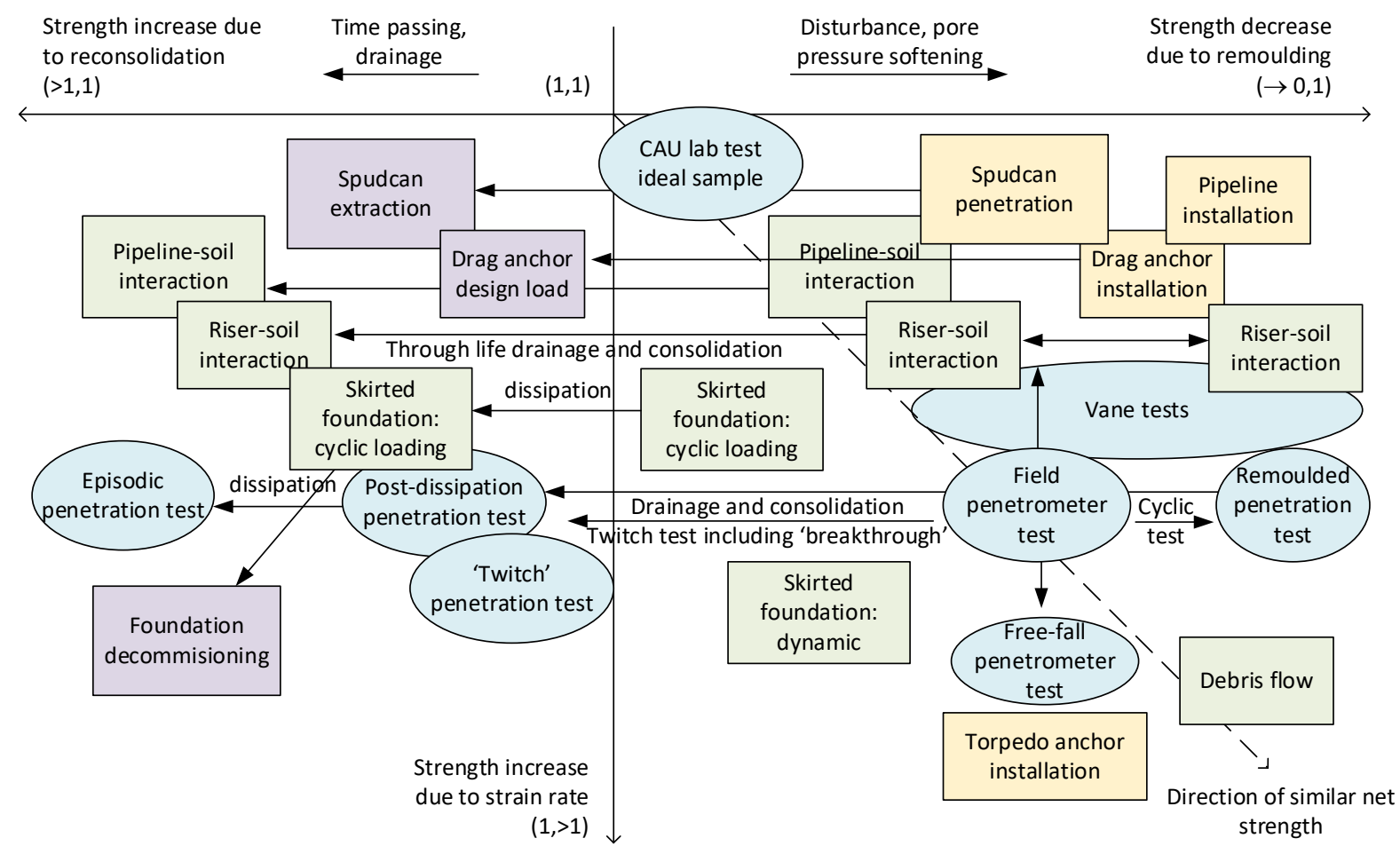

Fig. 1: Map of different soil tests and design cases (extended from Randolph et al. 2007)

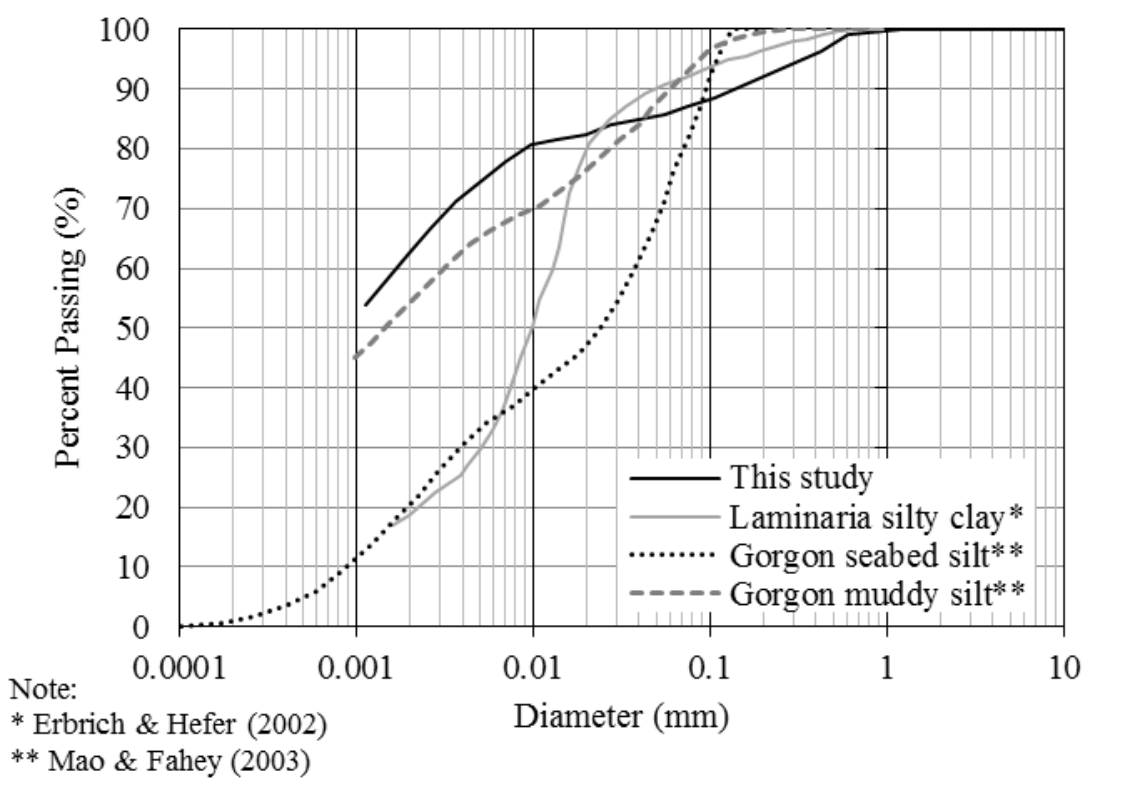

Fig. 2: Comparison of particle size distributions of various natural calcareous soils 

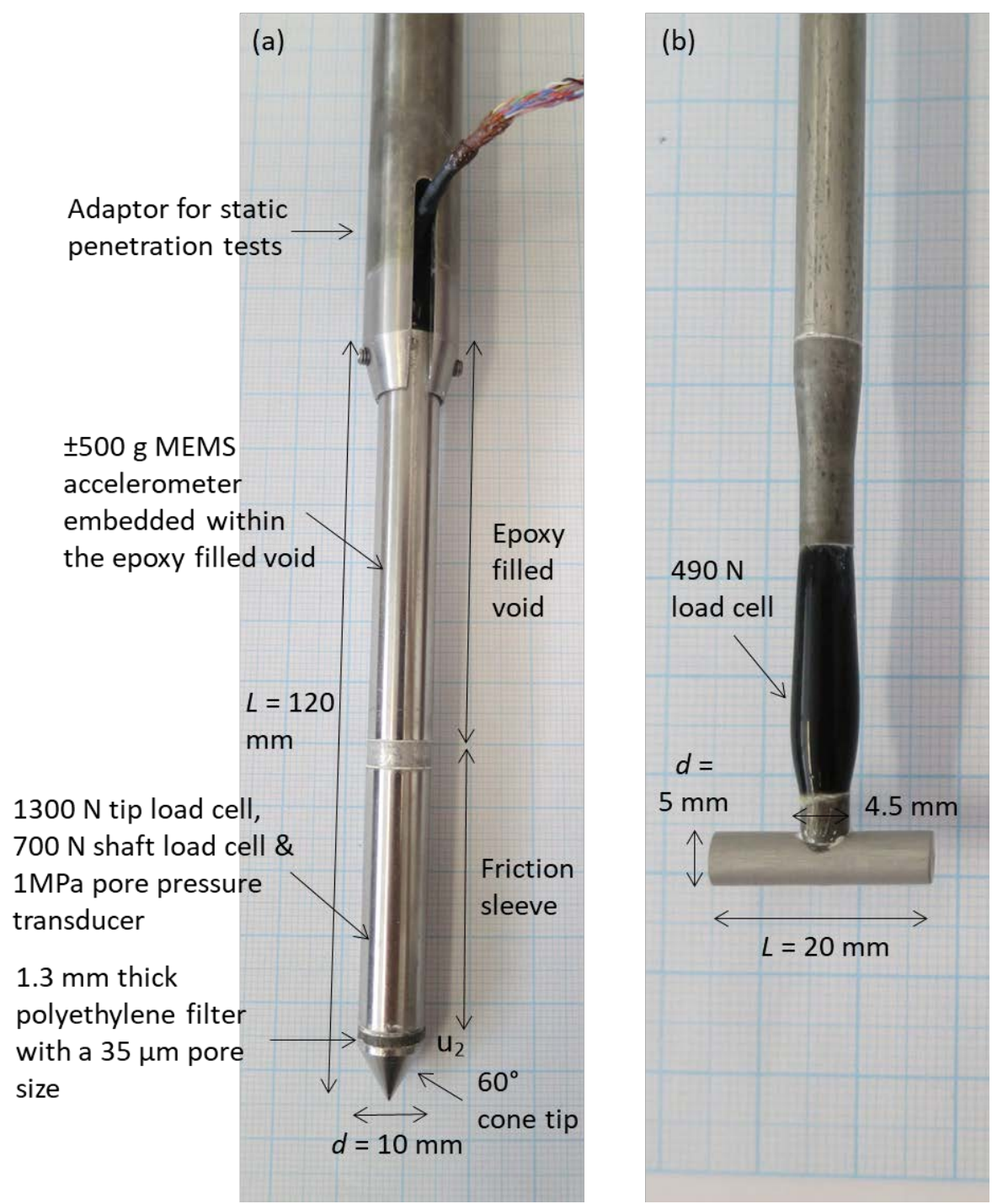

Fig. 3: Model penetrometers used in the centrifuge tests: (a) piezocone; and (b) T-bar 


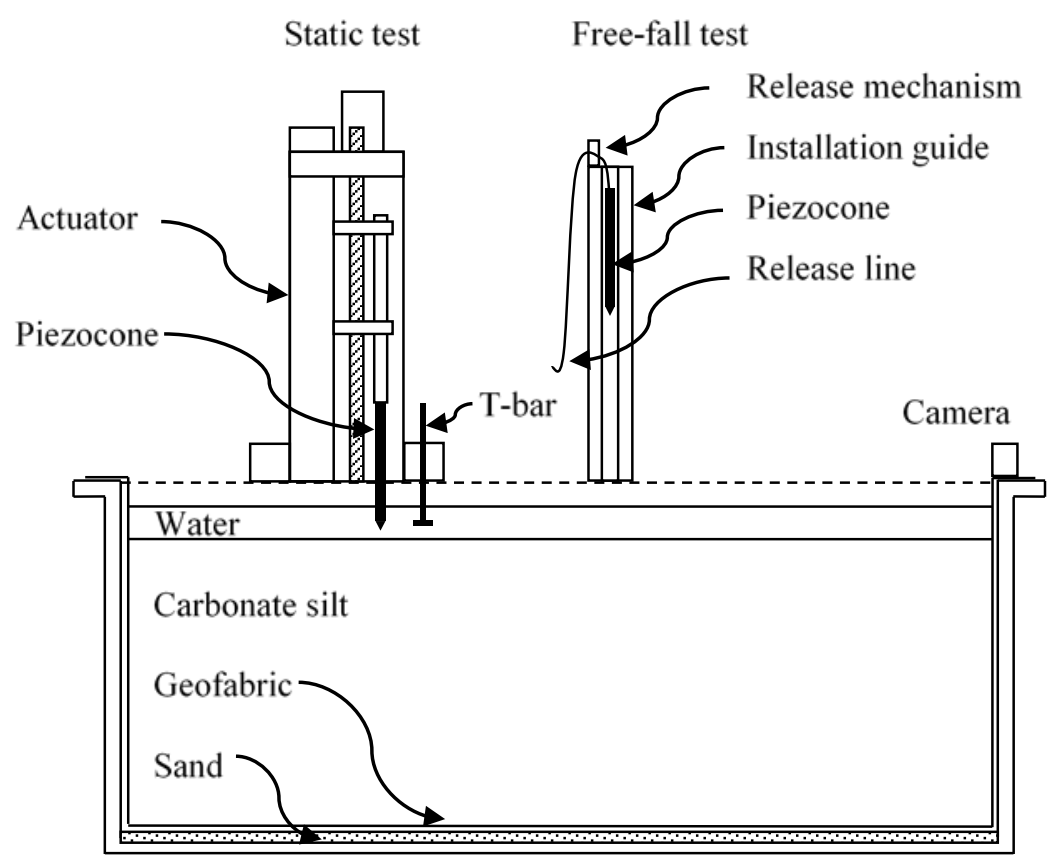

Fig. 4: Static and free-fall penetration test setup in the centrifuge

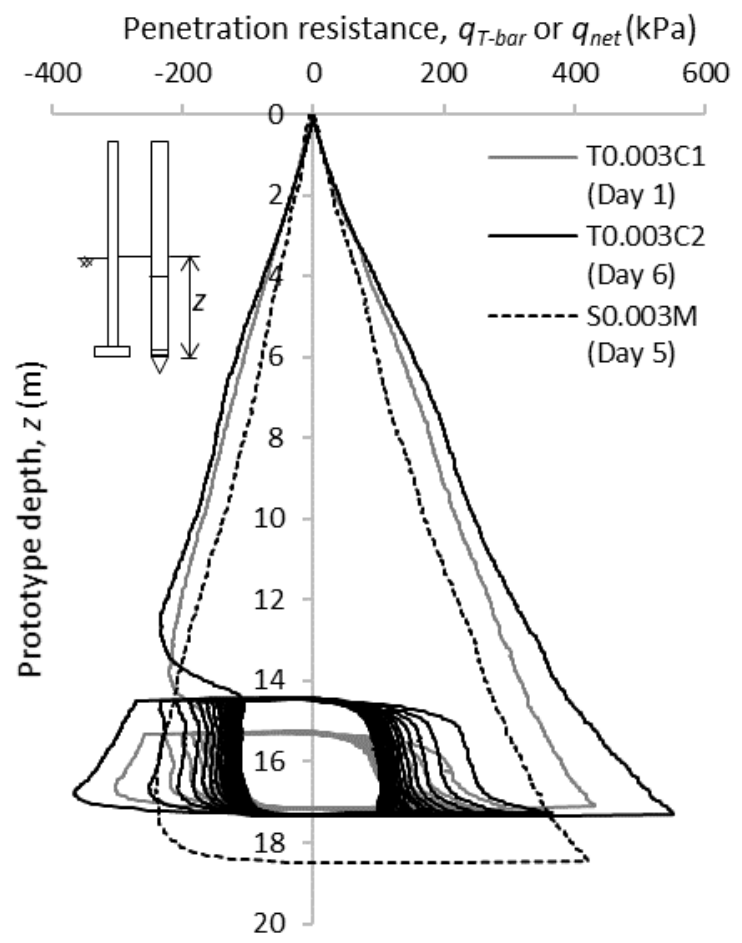

Fig. 5: Penetration resistance profiles obtained from static penetrometer tests 


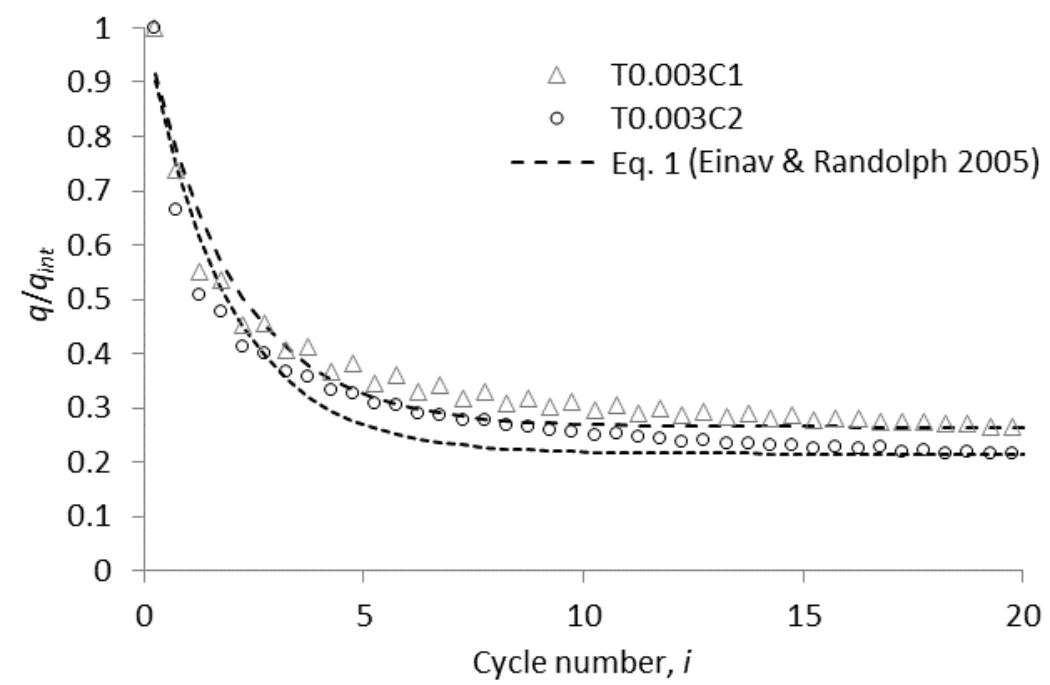

Fig. 6: Normalised cyclic degradation curves established from T-bar cyclic tests 

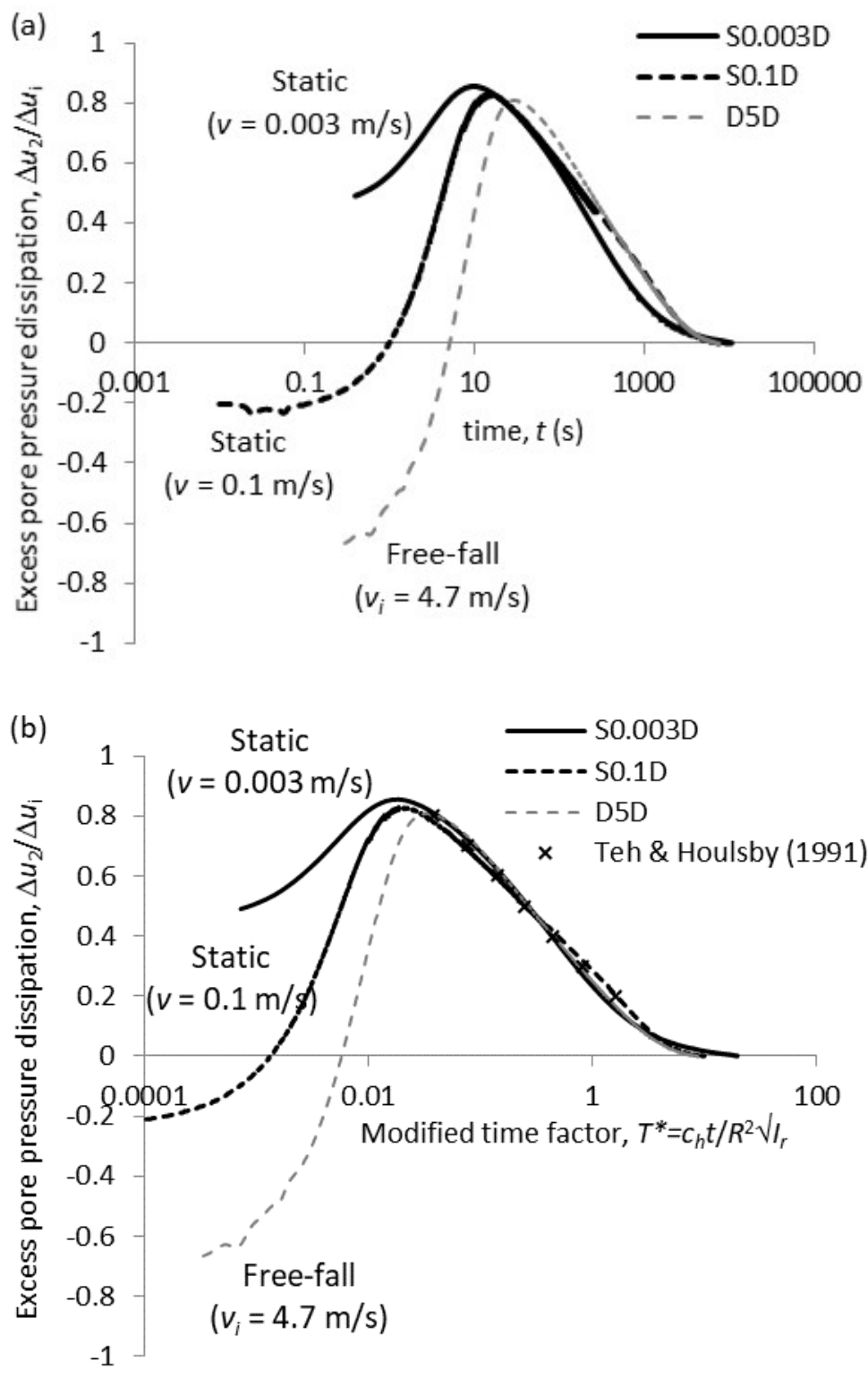

Fig. 7: Dissipation curves from static and free-fall piezocone tests 


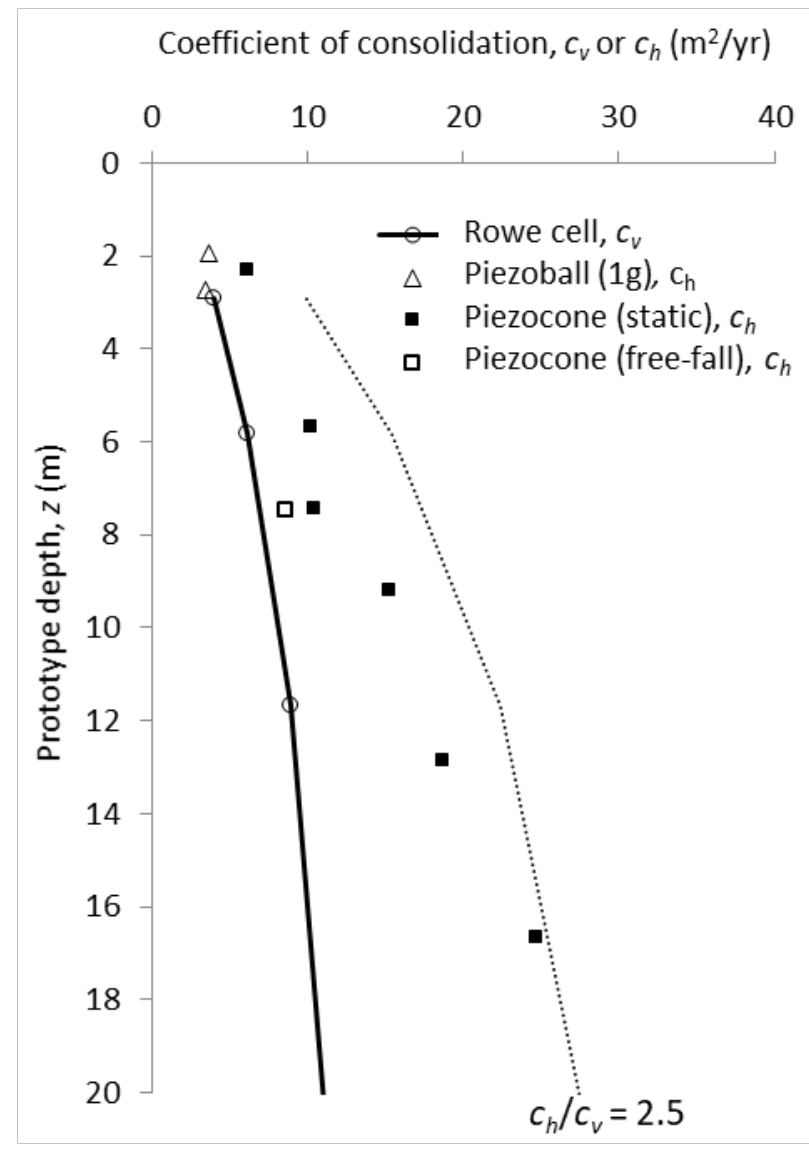

Fig. 8: Interpreted coefficient of consolidation for calcareous silt 

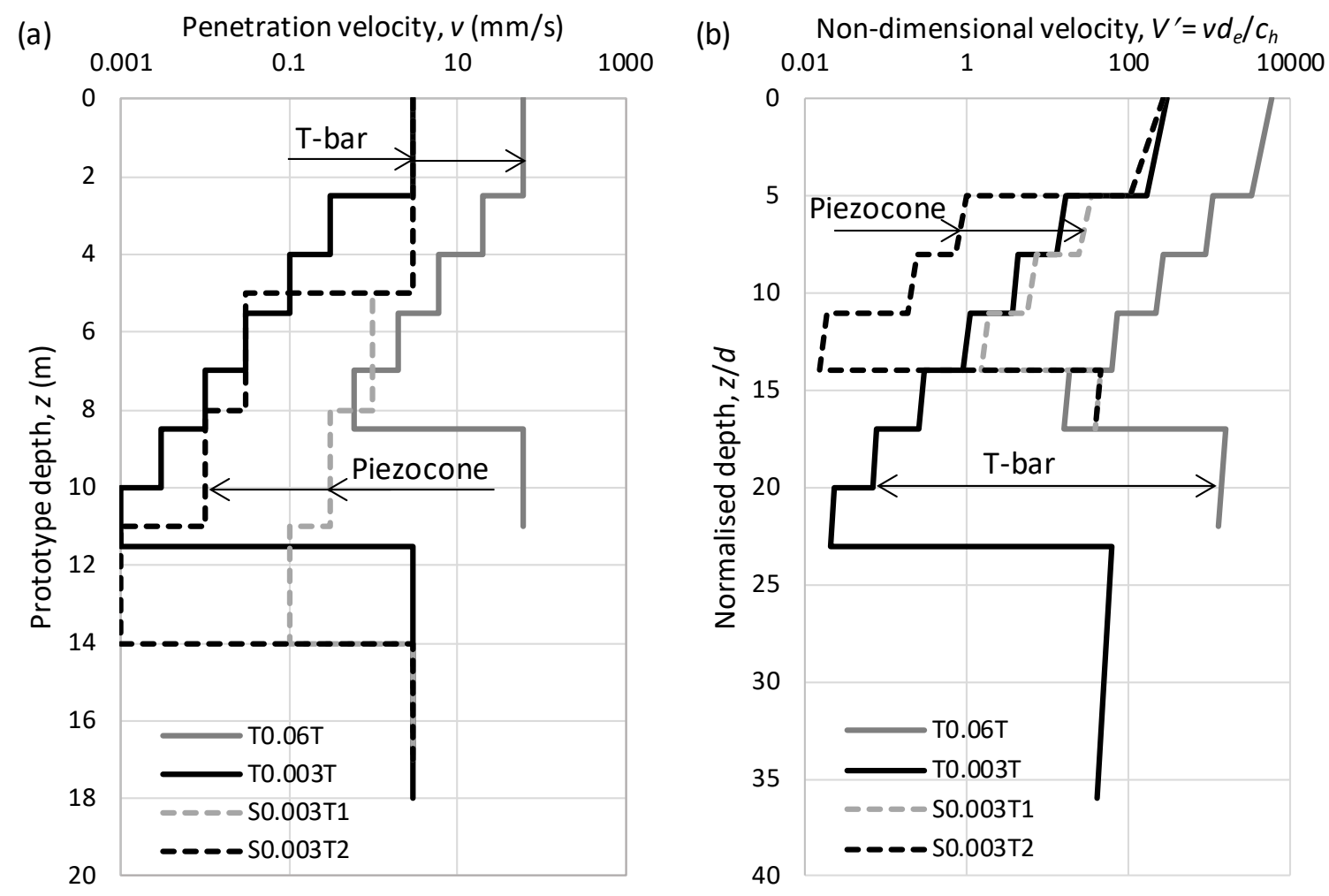

Fig. 9: Twitch test program for T-bar and piezocone

(a) Penetration resistance, $q_{\mathrm{T} \text {-bar }}(\mathrm{kPa})$

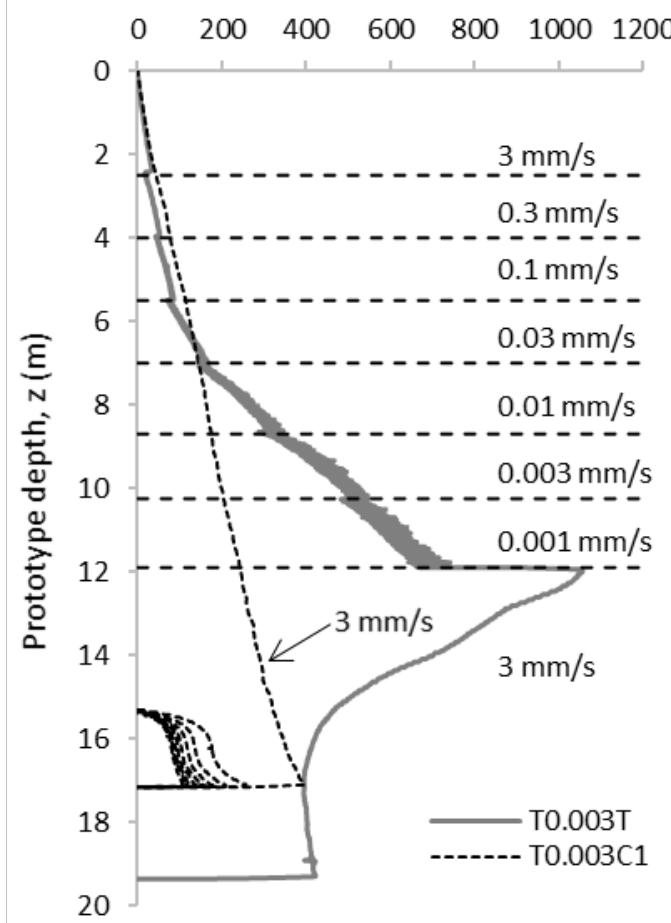

(b) Penetration resistance, $q_{\mathrm{T}-\text { bar }}(\mathrm{kPa})$

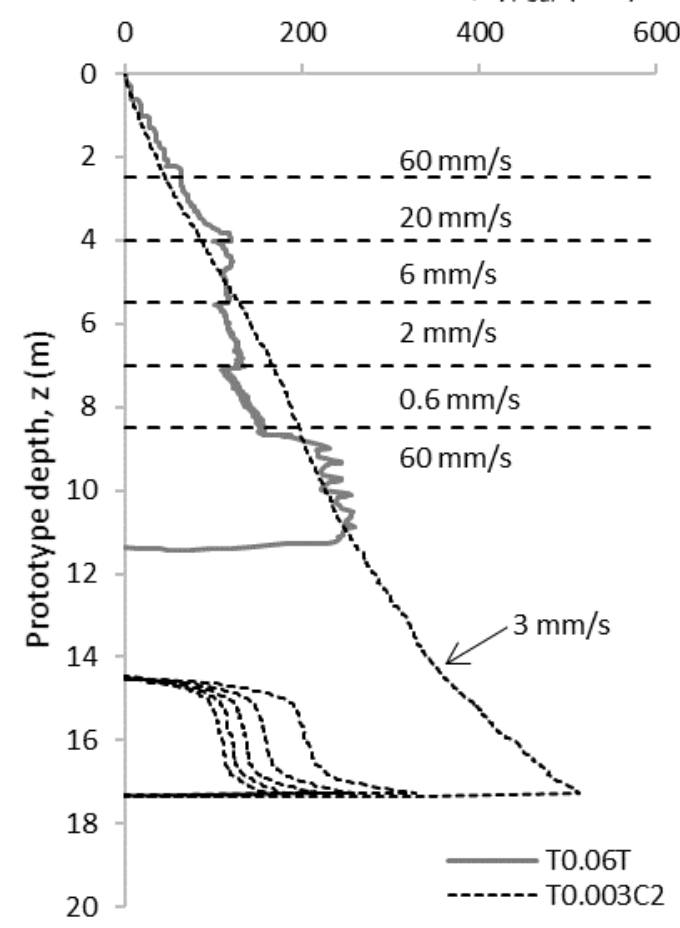

Fig. 10: Penetration resistance profiles of T-bar twitch tests 
(a) Net penetration resistance, $q_{\text {net }}(\mathrm{kPa})$

(b) Net penetration resistance, $q_{\text {net }}(\mathrm{kPa})$
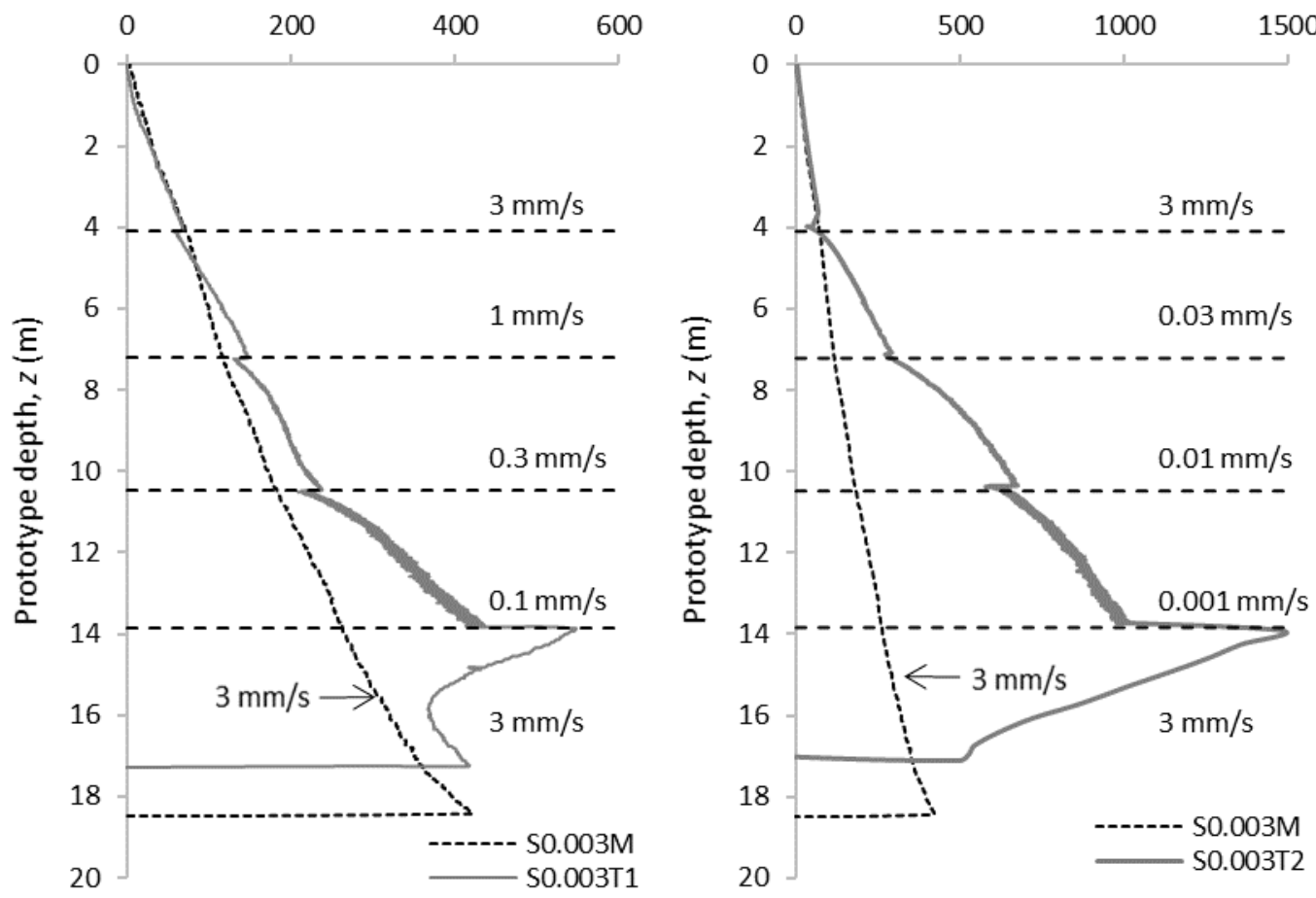

Fig. 11: Net penetration resistance profiles of piezocone twitch tests 
(a)

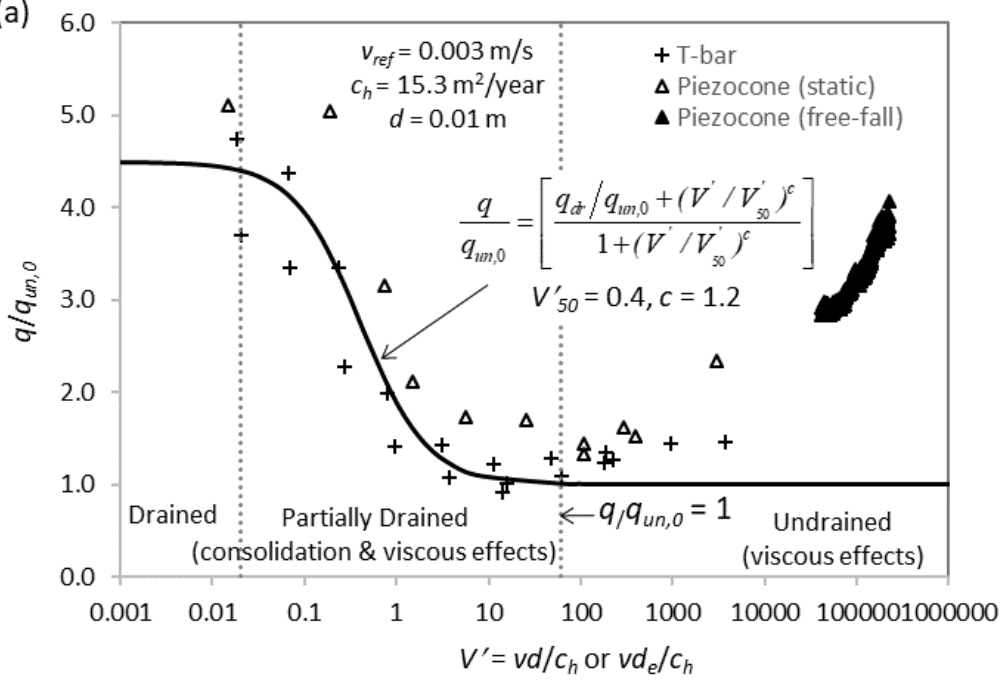

(b)

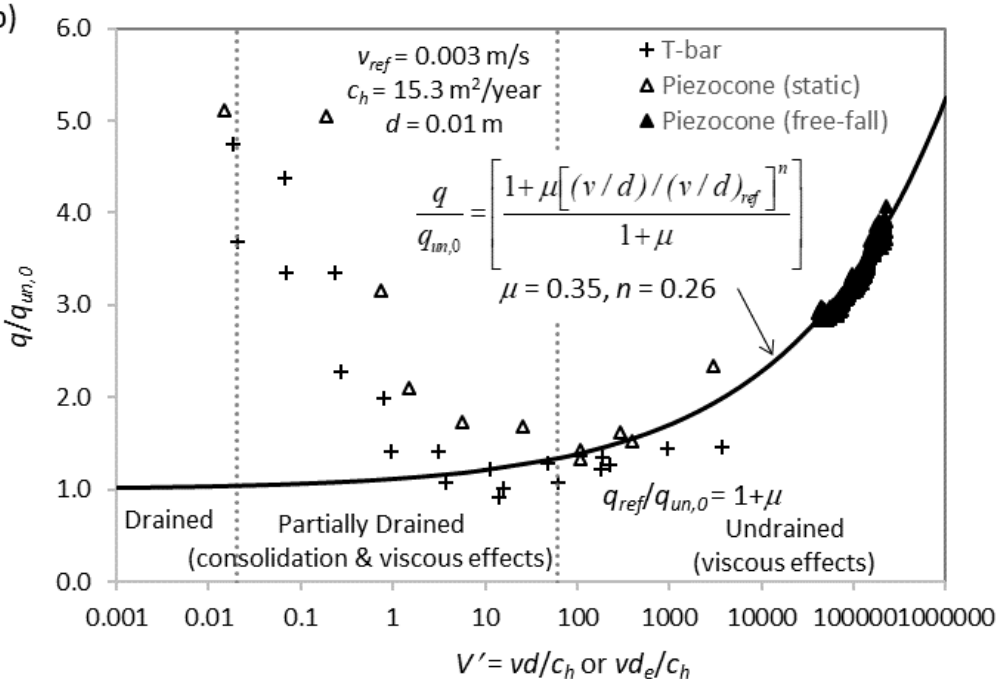

(c) 6.0

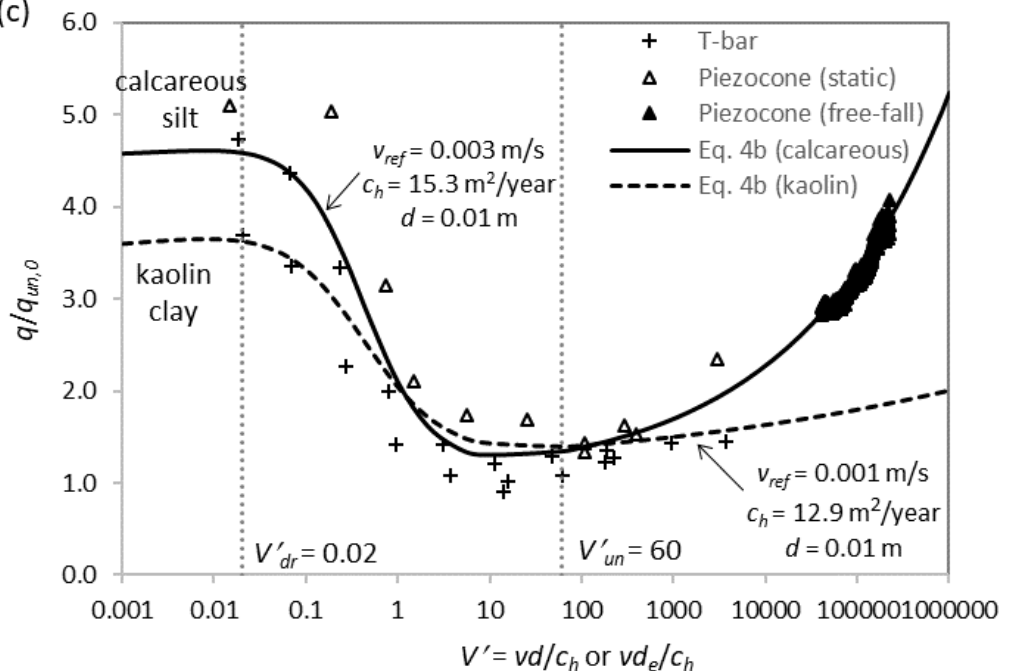

Fig. 12: Backbone curve derived from the various penetrometer tests: (a) consolidation effects; (b) viscous rate effects; and (c) combined response from consolidation and viscous effects 

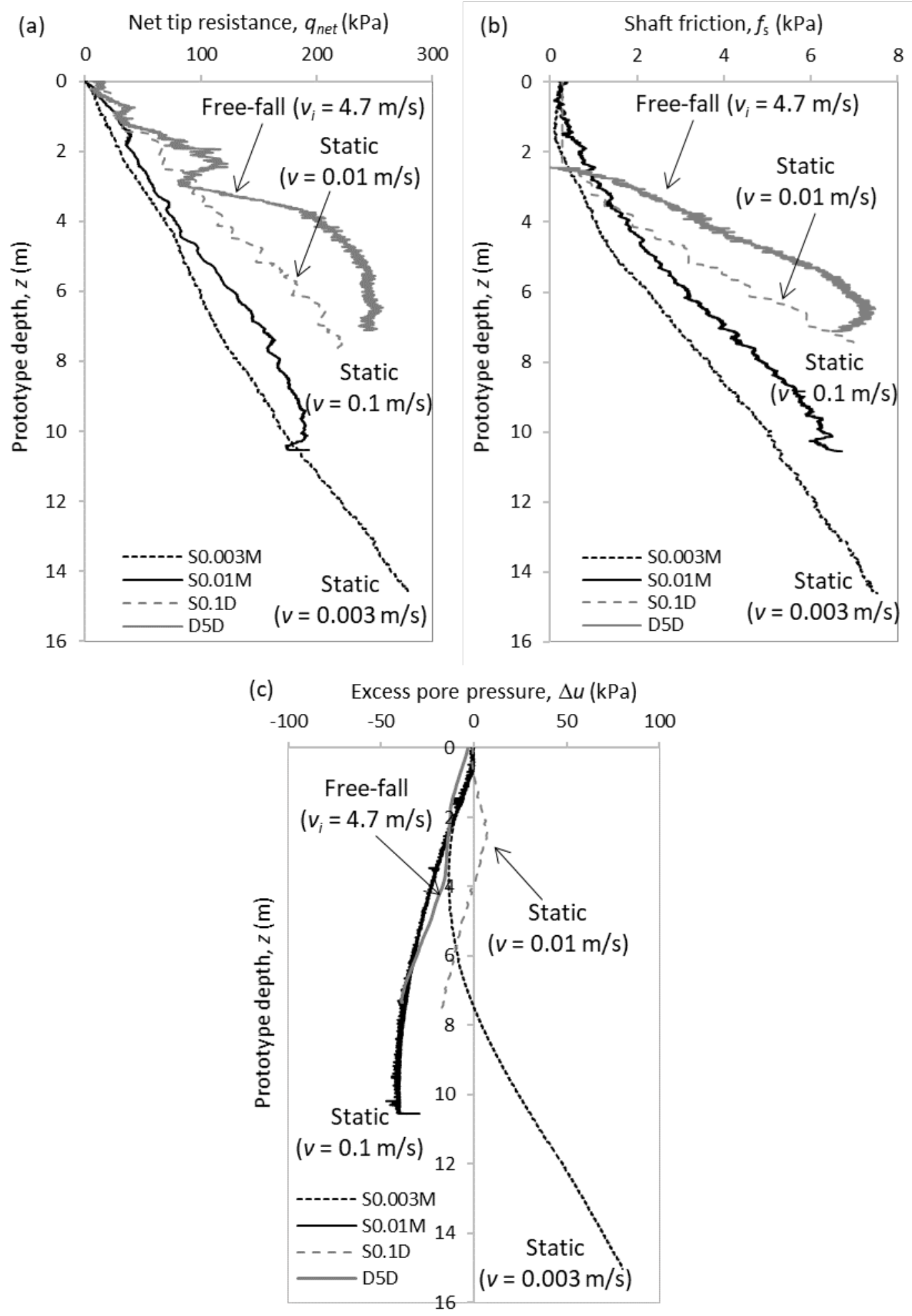

Fig. 13: Rate effects in piezocone tests: (a) net tip resistance; (b) sleeve friction; (c) excess pore pressure 

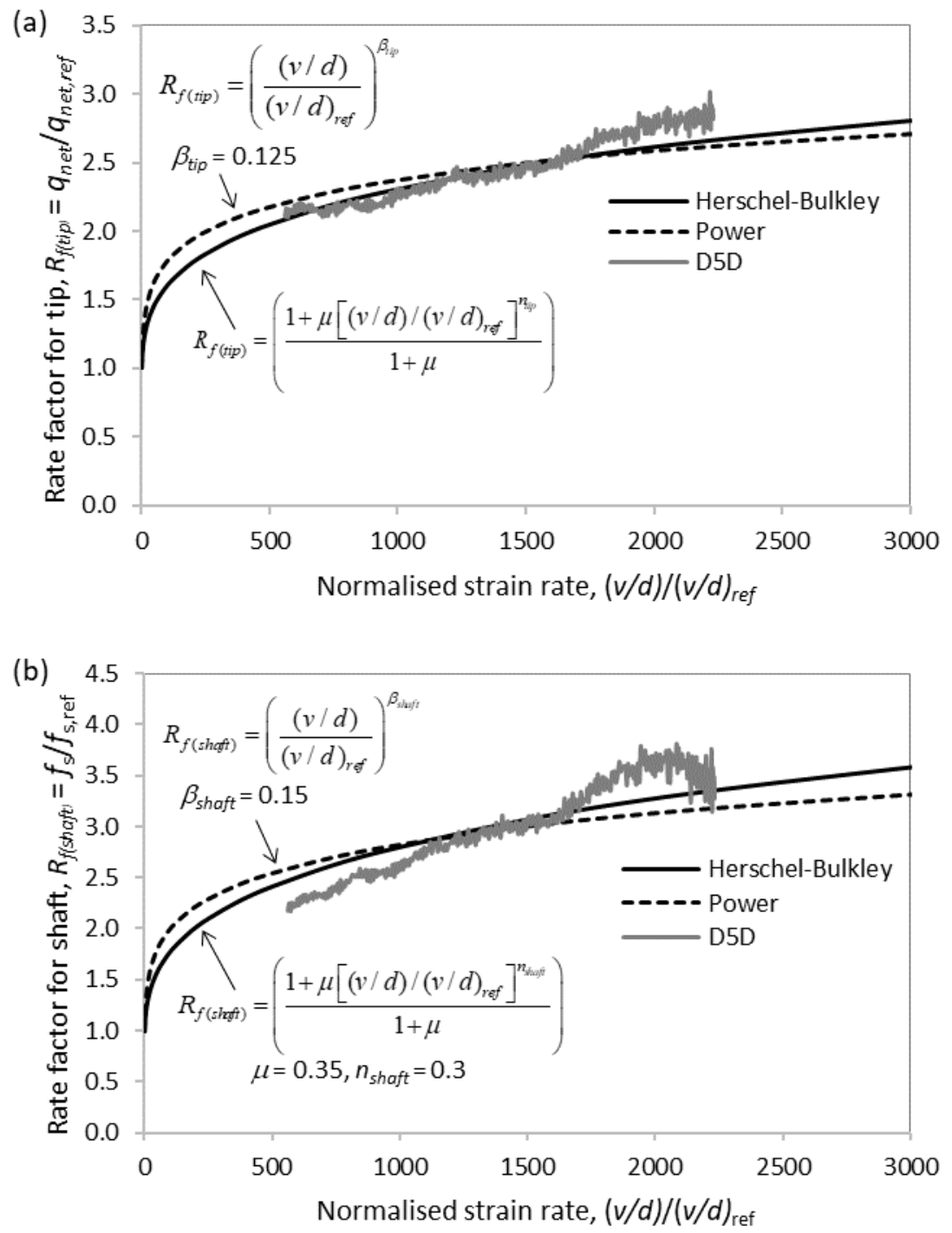

Fig. 14: Back-analysed strain rate parameters for free-fall piezocone test D5D $\left(v_{i}=4.7 \mathrm{~m} / \mathrm{s}\right)$ : (a) net tip resistance; (b) sleeve friction 
(a) Net penetration resistance, $q_{\text {net }}(\mathrm{kPa})$

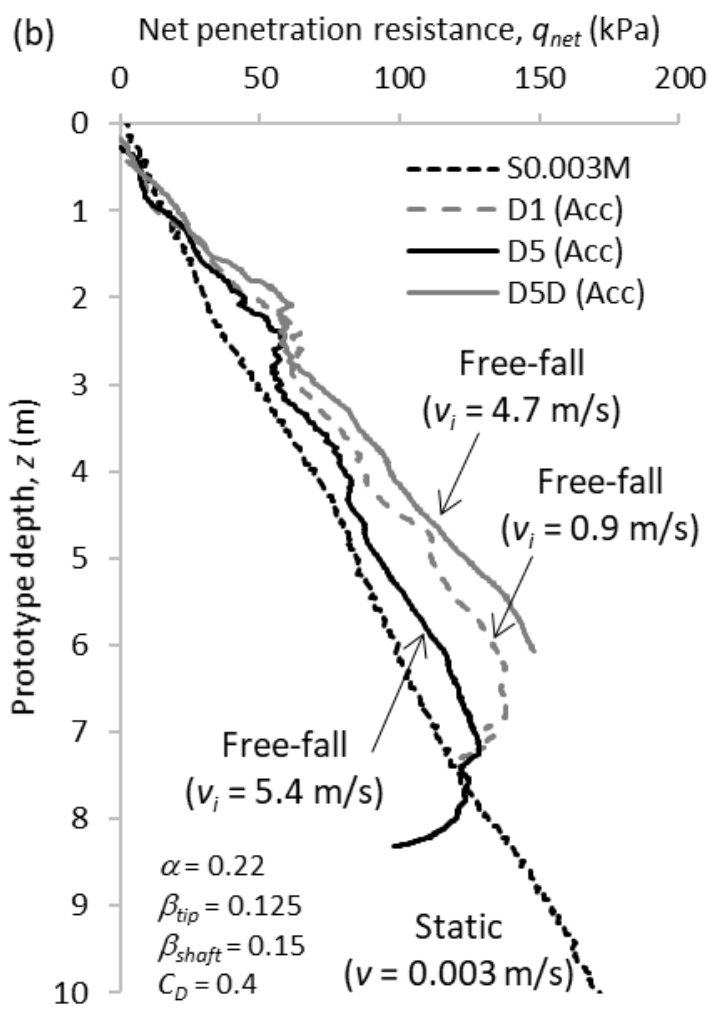

Fig. 15: Comparison between the static and free-fall piezocone net penetration resistance using: (a) tip load cell (LC) method; (b) accelerometer (Acc) method
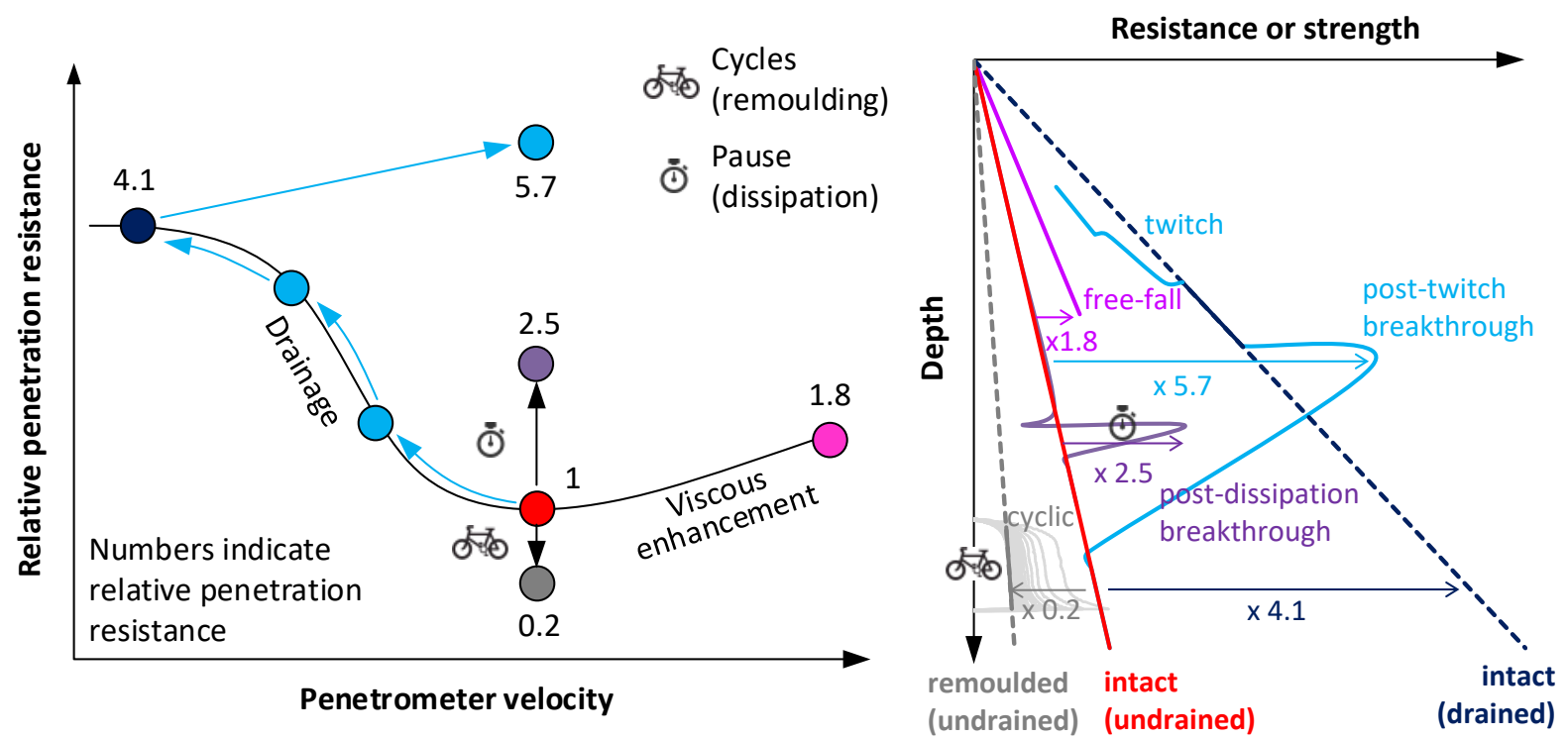

Fig. 16: Penetration resistances measured in different penetrometer tests or test stages 